\title{
El derecho a la vivienda y la dialéctica entre descentralización y recentralización
}

Andrei Quintiá Pastrana*

DOI: https://doi.org/10.47623/ivap-rvap.109.2017.1.07

\begin{abstract}
Sumario: I. Introducción. - II. El impacto de la descentralización en el desarrollo y subjetivación del derecho de vivienda: 1. El derecho a la vivienda como un derecho subjetivo. 2. Los legisladores estatal y autonómico ante el derecho de habitación. 3. Reino Unido y Escocia: La exigibilidad del derecho en el marco internacional.III. Acción pública y soluciones coactivas. La respuesta del legislador autonómico a la situación de emergencia habitacional: 1. Las reformas autonómicas de 2013. 2. Asiento de la reforma autonómica: Decreto-ley 6/2013 de Andalucía, Ley 24/2013 de Navarra y Ley $2 / 2014$ de Canarias. 3. Acción pública y grandes propietarios: Las leyes 3/2015 de Euskadi y 24/2015 de Cataluña. 4. Las reformas tras la respuesta del Tribunal Constitucional: Las leyes 10/2016 de Aragón, 2/2017 de Valencia, la ley 2/2017 de Extremadura y el proyecto de ley balear.-IV. La respuesta del Tribunal Constitucional a las soluciones autonómicas: 1. La aproximación formal: caso de extraordinaria necesidad y límites materiales del presupuesto habilitante. A. El caso de extraordinaria necesidad. B. Los límites materiales del presupuesto habilitante. El derecho de propiedad y el derecho de vivienda. C. Carácter subjetivo del derecho a la vivienda. 2. Un nuevo reparto competencial en materia de vivienda. A. La hipótesis de la distorsión del mercado hipotecario. B. Existencia de legislación estatal sobre la materia. C. Transgresión de las bases estatales. 3. Un paso adelante: el caso de la STC 62/2016. -V. Conclusiones
\end{abstract}

\footnotetext{
* Armela-Red de Investigación en Igualdad, Derechos y Estado Social, USC. Este trabajo se encuadra en el Proyecto «Vulnerabilidad social, crisis económica y derecho a la vivienda. Las políticas públicas de garantía social» (DER2016-79913-R).
} 


\section{Introducción}

La crisis financiera e inmobiliaria que se desató en 2007 generó un reparto desigual de perjuicios y beneficios entre los implicados en el mercado hipotecario. En 2014 el Consejo General del Poder Judicial cifró en 346.784 los lanzamientos practicados desde el 2008, de los cuales 104.430 se realizaron solo entre enero de 2013 y junio de 2014(1). Esta situación de emergencia habitacional justificó, a ojos de algunos legisladores autonómicos, el desarrollo de un instrumento que dotase de contenido subjetivo al derecho a la vivienda.

Dicho desarrollo consistió en una serie de reformas promulgadas entre 2013 y 2017, que fueron impugnadas por el Ejecutivo central ante el Tribunal Constitucional. Las reformas se caracterizan por reconocer el ejercicio de una acción pública en materia habitacional y crear procedimientos destinados a la conservación de la vivienda habitual que fuese objeto de desahucio o a la incorporación al parque público de inmuebles desocupados. Los recursos del Ejecutivo, por su parte, se fundamentaron en una invasión competencial de los títulos exclusivos del Estado, al entender que estas normas afectan a la competencia estatal en materia de bases y coordinación de la planificación general de la actividad económica.

Por otra parte, desde una perspectiva de conjunto del panorama legislativo, parece que las Comunidades Autónomas mantienen una actitud más progresiva en cuanto al desarrollo de la vertiente subjetiva del derecho a la vivienda que los poderes centrales. Aproximarse al estudio de esta aparente correlación entre descentralización y refuerzo de los títulos sociales permitiría despejar ciertas dudas sobre el debate generado alrededor de esta cuestión.

Se ha discutido mucho en la doctrina y la jurisprudencia sobre la exigibilidad del derecho a la vivienda ante los tribunales ordinarios, sin embargo el poder legislativo no ha entrado a abordar esta cuestión sino a partir del estallido de la burbuja inmobiliaria. Así, el carácter subjetivo de este derecho ha sido, hasta ahora, una disquisición más teórica que práctica.

Este estudio pretende acercarse en profundidad a la relación entre la descentralización y centralización legislativa y el desarrollo del derecho a la vivienda, centrándose para ello, en la observancia de las características básicas de las reformas autonómicas promulgadas a partir de 2013 y en la Sentencia del Tribunal Constitucional 93/2015.

(1) "Comunicado desahucios y sobreendeudamiento en España» de Jueces para la democracia [Consultado en línea en http://juecesparalademocracia.blogspot.com.es/2014/11/comunicado-desahucios-y.html el 30 de julio de 2017] 


\section{El impacto de la descentralización en el desarrollo y subjetivación del derecho de vivienda}

\section{El derecho a la vivienda como un derecho subjetivo}

El desarrollo del derecho a una vivienda digna y adecuada en nuestro ordenamiento está estrechamente conectado con la cláusula del Estado social (2). Se integra, junto a otros títulos sociales, en el Capítulo III de la Sección II del Título I de la Constitución, bajo la rúbrica de «principio rector de la política social y económica», lo que ha determinado que para el Constitucional no se trate de un auténtico derecho subjetivo, sino de un principio rector o un mandato de optimización a los poderes públicos (3).

Buena parte de la doctrina, actualmente, discrepa con el Alto Tribunal y sí reconoce el carácter subjetivo del derecho, sin embargo las posiciones no son uniformes. Para algunos autores, como Ponce, se trata de un derecho subjetivo del que se deriva un mandato ineludible al legislador para que articule los medios necesarios para la determinación de su aplicación, alcance y extensión(4). Para López, igualmente, estamos ante un verdadero título configurado constitucionalmente, si bien admite que su sentido subjetivo podría también ser identificado "en todo caso como consecuencia del desarrollo legislativo producido en la materia" pues "cuenta ya con el desarrollo legal que se exige en el art. 53.3 de la Constitución Española para poder alegar dicho derecho ante la jurisdicción ordinaria» (5). Maguregui no entra a discutir la naturaleza del art. $47 \mathrm{CE}$, pero es firme cuando describe la existencia de un derecho subjetivo en la reciente legislación vasca de vivienda (6). Tornos (7) coincide parcialmente con la jurisprudencia del TC al entender que el art. $47 \mathrm{CE}$, en tanto que precepto, no contiene un auténtico derecho subjetivo, sin embargo sí considera que impone un mandato al legislador para el desarrollo de di-

(2) Cfr. JARIA I MANZANO, Jordi, «El derecho a una vivienda digna en el contexto del Estado social» en El acceso a la vivienda en un contexto de crisis. Edisofer. Madrid, 2011, pág. 58

(3) Cfr. PONCE, Juli, "La tutela judicial del derecho a la vivienda y el papel del Tribunal Constitucional español: luces y sombras en el contexto europeo e internacional» en Derecho a la vivienda y función social de la propiedad. Nuevas políticas en el marco del servicio público de alojamiento. Cizur Menor. Navarra, 2017, pág. 73

(4) Íbid, pág. 62

(5) Cfr. LÓPEZ RAMÓN, Fernando, Construyendo el derecho a la vivienda. Marcial Pons. Madrid, 2010, págs. 13 y 16

(6) Cfr. MAGUREGUI, Íñigo, "Ley 3/2015. El derecho a la vivienda como derecho subjetivo" en Urbaniker, 2015 [Consultado en línea el 6 de julio de 2017 en http://urbaniker.net/p?=822]

(7) Cfr. TORNOS MAS, Joaquín, "Las viviendas desocupadas y la función social de la propiedad" en Derecho a la vivienda y función social de la propiedad. Nuevas políticas en el marco del servicio público de alojamiento, 2017, págs. 149 y 150 
cho sentido subjetivo y -al igual que Maguregui- deduce que este mandato se ha cumplido en la legislación en materia habitacional de Euskadi. Por tanto, aunque no existe una interpretación uniforme, sí parece predominar un sector de la doctrina que entiende que en la legislación ordinaria se ha configurado un auténtico derecho subjetivo a la vivienda en atención a un mandato del constituyente.

La primera incorporación a la legislación ordinaria del derecho la realiza el legislador estatal, mediante una transposición ampliada del precepto constitucional (8) y se produce en la Ley 8/2007 del suelo, hoy integrada en el Real Decreto legislativo 7/2015(9). Esta disposición completa el contenido material del art. 47 CE con una serie de previsiones reconocidas en los textos internacionales, como la garantía de que el hogar no se vea afectado por contaminaciones ambientales o acústicas. Se trata de una progresión en el desarrollo del derecho pues lo dota de mayor alcance, sin embargo la ley no incorpora ningún tipo de acción o procedimiento para su ejercicio, volviéndolo así virtual e inexigible. El legislador estatal tuvo en sus manos la oportunidad de darle un contenido subjetivo al derecho a la vivienda en aplicación del art. 53.3 CE y, no obstante, optó por no hacerlo, configurándolo como un mero principio rector.

En el mismo año se promulga en Cataluña la Ley 18/2007 de derecho a la vivienda que, a diferencia de la norma estatal, en su artículo 6 sí reconoce el ejercicio de una acción pública ante la jurisdicción ordinaria. Por medio de este precepto se articula por primera vez en nuestro ordenamiento la exigibilidad del derecho. Así mismo, en su art. 42, esta ley recogía un procedimiento expropiatorio - hoy derogado por una ley posterior - que contemplaba la imposición de un alquiler forzoso a las viviendas deshabitadas sobre la base de un nuevo sentido de la función social de la propiedad sobre la vivienda: la obligación de mantenerlas ocupadas. El legislador catalán había profundizado más que el estatal a la hora de desplegar el contenido subjetivo del derecho a la vivienda reconociendo una acción y un procedimiento para demandar su aplicación ante la Administración y los tribunales.

Tras la aprobación de la norma catalana, el siguiente texto de interés en términos de desarrollo subjetivo del derecho a la vivienda fue la ley

(8) El art. 5.1.a) del actual Texto Refundido de la Ley del suelo y rehabilitación urbana, que integra el derecho ya recogido en la Ley 8/2007 establece que "todos los ciudadanos tienen derecho a disfrutar de una vivienda digna, adecuada y accesible, concebida con arreglo al principio de diseño para todas las personas, que constituya su domicilio libre de ruido u otras intromisiones contaminantes de cualquier tipo que superen los límites máximos admitidos por la legislación aplicable y en un medio ambiente y un paisaje adecuados".

(9) Cfr. VAQUER CABALLERÍA, Marcos, La eficacia y la efectividad del derecho a la vivienda en España. lustel. Madrid, 2011, pág. 63 
manchega 1/2011, de 10 de febrero, que preveía, no sólo la configuración de una auténtica acción pública en materia de vivienda, sino que, a diferencia de la ley catalana, además, la dotaba de recursos para hacerla materialmente aplicable. No obstante, la vigencia de la norma fue escasa y fue derogada por el propio parlamento manchego el 21 de febrero del 2012.

Este primer contraste entre la legislación autonómica y la estatal con respecto al derecho a la vivienda perfila una tendencia que se mantuvo en el tiempo y que cristalizó en la ola de reformas autonómicas en materia habitacional de 2013, iniciada por el Decreto-ley andaluz 6/2013 y sostenida por la ola de reformas Estatutarias que, desde el 2006, recogen el derecho en su texto. De hecho, el reconocimiento en la legislación ordinaria de una acción para el ejercicio del derecho, a día de hoy, solo se halla en dos leyes más, ambas autonómicas y surgidas en el marco de dicha ola, la Ley 3/2015 de Euskadi y la Ley 2/2017 de Valencia.

Esta ola de reformas se caracteriza por el desarrollo de unos mecanismos expropiatorios o sancionadores orientados a amortiguar los efectos del desahucio derivado de una ejecución hipotecaria recaída sobre ciertos sujetos vulnerables, así como a agregar viviendas deshabitadas al parque de alquiler social. Salvo las normas valenciana y extremeña, todas fueron recurridas por el Gobierno ante el Tribunal Constitucional, sin embargo, hasta la fecha solo se ha resuelto el recurso sobre el Decreto-ley andaluz que ha concluido con la derogación parcial de la norma mediante la STC 93/2015, de 14 de mayo.

En el fundamento decimoséptimo de dicha sentencia, el Tribunal Constitucional afirmó que es el Estado el que define "la extensión de la intervención pública de protección de personas en situación de vulnerabilidad" con respecto al mercado hipotecario y que, al mismo tiempo, el mismo Estado «impide que las Comunidades Autónomas en ejercicio de sus competencias propias adopten disposiciones que, con este mismo propósito de tutela, afecten de un modo más intenso a dicho mercado".

La tesis es sencilla: Ias Comunidades Autónomas no podrán superar el nivel de protección social establecido por los poderes centrales, imponiendo así a las Autonomías un límite para el desarrollo de coberturas públicas, incluso en el marco de sus propios títulos competenciales. Lo que comporta en la práctica una supeditación de los títulos sociales - en concreto del derecho a la vivienda - a las necesidades de los mercados.

No obstante, el Tribunal Constitucional no parece que siempre haya seguido esta tesis. Al contrario, en la importante STC 152/1988, de 20 de julio, donde desarrolló y sentó los criterios sobre la relación de los títulos del art. 148.1.3 y el art. 149.1.13 CE establecía que las autonomías «pue- 
den definir y llevar a cabo una política de vivienda propia, complementando las actuaciones de protección y promoción previstas por el Estado". En este pronunciamiento el Tribunal entendía que el Decreto estatal, impugnado por el Gobierno vasco, que dio origen al recurso podía definir actuaciones protegibles, sin perjuicio de que "la Comunidad Autónoma del País Vasco pueda, en virtud de su política de vivienda, conforme al art. 10.31 del EPV, definir otro tipo de actuaciones protegibles».

El Estado ha buscado una progresiva ampliación de sus competencias y lo ha hecho con el fin de intervenir en la ejecución de distintos procedimientos e instrumentos administrativos dirigidos a la protección de sujetos especialmente vulnerables $y$, en concreto por lo que nos ocupa, en materia de derecho a la vivienda. El Tribunal Constitucional, sobre la base de una interpretación amplia del art. 149.1.13 CE, avala ese movimiento centrípeto del Estado, desdibujando el modelo autonómico y social. Movimiento que favorece los intereses de los principales agentes mercantiles y financieros y opera en detrimento de las regulaciones más proactivas con los intereses de los sectores sociales vulnerables, desarrolladas por las Comunidades Autónomas.

Resulta llamativo, de hecho, que principalmente se articule la entrada en la competencia de vivienda por medio del título sobre las bases y la coordinación de la planificación económica y no a través del título contenido en el ordinal primero del $149.1 \mathrm{CE}$, que habilita al Estado para regular las condiciones básicas que garantizan la igualdad de todos los españoles y que juega un importante papel en el desarrollo estatal de los derechos sociales. Como afirma Ponce, «en la regulación estatal actual [...] parece carecerse de una preocupación por fijar una garantía mínima del derecho a la vivienda y del derecho a la igualdad [...] que podría estar justificada mediante el art. 149.1.1 CE»(10).

\section{Los legisladores estatal y autonómico ante el derecho de habitación}

Esta correlación, parece no restringirse solo al ámbito del derecho de vivienda y se presenta como una constante en términos históricos. Así, según Cabrillo Rodríguez, "[I]a centralización de la regulación fue vista [...] en España durante mucho tiempo como un instrumento para la liberalización de la actividad económica». Y frente a esta posición liberalizadora y centralizante del Estado, según el autor, en muchas ocasiones las Comunidades Autónomas ocupan un rol más centrífugo al tiempo que

(10) PONCE SOLÉ, Juli, «Políticas públicas para afrontar la regeneración urbana de barrios degradados. Una visión integrada desde el Derecho» en Revista Aragonesa de Administración Pública núm. 41-42, pág. 24 
más proclive a la protección social, desarrollando normas que intervienen con mayor intensidad en el mercado de lo que lo hacen el legislador y el ejecutivo central (11).

En materia de vivienda esta tesis parece comprobarse al comparar el papel del Estado y las CCAA en el desarrollo del derecho. Inscrito en la Constitución como un principio rector de la política económica, ha sido subjetivado, únicamente, por obra de la acción de legisladores autonómicos. Es especialmente destacable que, precisamente, aquellas Comunidades con una vocación de asentamiento competencial más importante como Cataluña, País Vasco o, recientemente, Valencia destacan precisamente por abanderar este proceso de subjetivación del derecho al haber desarrollado las únicas normas en nuestro ordenamiento que articulan una acción pública para su ejercicio.

Esta labor subjetivadora se refleja, también, en la literatura. RuizRico (12) señala, por ejemplo, la incorporación al Estatuto de Autonomía de Cataluña de un procedimiento judicial especial de defensa de derechos sociales que dotaría de exigibilidad ante los tribunales derechos considerados, hasta ahora, meramente "programáticos» e inexigibles, como la vivienda. Este procedimiento fue, posteriormente, desactivado por el Constitucional en su Sentencia 31/2010 de 28 de junio.

En todo caso, son las reformas autonómicas posteriores a 2013 las que destacan en el proceso descentralizador y subjetivador. Estos instrumentos aprobados en Andalucía, Canarias, Navarra, País Vasco, Cataluña, Valencia, Aragón y Extremadura -y que más adelante analizaremos en detalle - han querido dotar a las Administraciones Públicas de recursos y procedimientos necesarios para la exigibilidad material del derecho. Todas ellas, salvo las normas valenciana y extremeña, han sido recurridas por el Gobierno ante el Tribunal Constitucional.

Desde una perspectiva técnico-jurídica es importante resaltar que las reformas desarrollan, no solo un derecho subjetivo de acceso a la vivienda, sino también un derecho subjetivo a la permanencia en la vivienda, siendo pioneras por ello en el ámbito comparado. Contienen un sistema expropiatorio y sancionador al que pueden acogerse las personas vulnerables afectadas por un procedimiento de desahucio para mantener su posesión en la vivienda durante un periodo adicional tras el lanzamiento para mantener su posesión en la vivienda durante un periodo adicional tras el lanzamiento. Además, las leyes vasca y valenciana reco-

(11) CABRILLO RODRÍGUEZ, Francisco, "Unidad de mercado y competencia regulatoria» en Información Comercial Española, ICE: Revista de economía núm. 871, 2013, págs. 29 y 30

(12) Cfr. RUÍZ-RICO, Gerardo, «Derechos sociales y reforma de los estatutos de autonomía: el derecho a la vivienda" en Nuevas Políticas Públicas: Anuario multidisciplinar para la modernización de las Administraciones Públicas núm. 2, 2006, pág. 87 
nocen el ejercicio de una acción pública para exigir ante los tribunales y ante la Administración la asignación de una vivienda de manera efectiva.

Por el contrario, el legislador estatal, que ha buscado diversas vías para entrar en la competencia en materia de vivienda, parece servir de freno a esta subjetivación. Lay ley $8 / 2007$, hoy integrada en el Real Decreto legislativo $7 / 2015$, fue el primer texto ordinario en recoger el derecho a la vivienda en nuestro ordenamiento, renunciando a expresar en él ninguna acción o procedimiento para su ejercicio. Igualmente, el ejecutivo central, aun sucediéndose distintos avatares políticos, se hace notar por la falta de desarrollo de un Reglamento que le de contenido al concepto de "vivienda vacía» de la Ley de haciendas locales, sin el cual es imposible articular ningún impuesto que grave este fenómeno (13)(14).

Se encuentra en trámite de aprobación el Plan estatal de vivienda 2018-2021, que integra un "Programa de ayuda a los desahuciados de su vivienda habitual». Curiosamente, este Plan se asemeja a las reformas autonómicas en materia de vivienda que el mismo Gobierno impugnó ante el Tribunal Constitucional, pues incorpora ciertas innovaciones introducidas, previamente, por el legislador autonómico en las referidas normas.

El plan supera uno de los estándares fijados en las reformas autonómicas al establecer un umbral mayor de lo que venían disponiendo estas para acogerse a las previsiones. No obstante, ofrece no solo menos coberturas en las prestaciones que estas leyes, sino también un mayor obstáculo para su exigibilidad, debido a su propia naturaleza jurídica no imperativa, que contrasta con el carácter de ley de los instrumentos autonómicos.

En síntesis, observamos una tendencia en las Comunidades Autónomas conducente al refuerzo y subjetivación del derecho a la vivienda (mediante el reconocimiento de una acción pública o el desarrollo de procedimientos encaminados a la conservación del mínimo vital) y una resistencia en la actividad del Estado a esta tendencia (a través de la interposición de recursos, o la renuncia a un desarrollo completo del contenido subjetivo del derecho).

(13) A estos efectos es necesario indicar que Navarra y País Vasco, que gozan de un régimen fiscal autónomo, sí han desarrollo un impuesto a las viviendas vacías a través del art. 184 Ley Foral 2/1995 de Haciendas Locales de Navarra y la Ley 3/2015 de Vivienda del País Vasco.

Cfr. SIBINA TOMÁS, Domènec, «EI parque residencial deshabitado en la legislación autonómica de vivienda: la perspectiva que ofrecen los recursos de inconstitucionalidad pendientes de resolución" en Derecho a la vivienda y función social de la propiedad. Nuevas políticas en el marco del servicio público de alojamiento. Cizur Menor. Navarra, 2017, pág. 89

(14) El Parlamento de Cataluña ha intentado desarrollar un impuesto sobre el fenómeno por medio de la Ley 14/2015, de 21 de julio, que ha sido recurrida por el Gobierno central. Con la admisión a trámite del recurso la ley fue inicialmente suspendida, si bien por medio del Auto 157/2016 de 20 de septiembre el Tribunal acordó el levantamiento de la suspensión. 
Podríamos encontrar, entonces, una cierta relación entre los procesos de descentralización y el desarrollo del derecho a la vivienda y, así mismo, entre los procesos de centralización y las resistencias a estos desarrollos. Para Cabrillo, esta llamativa relación viene motivada por la propia tensión inherente a las relaciones centro-periferia:

"hay varios argumentos que incitan al político autonómico a legislar en un gran número de cuestiones y a tratar de controlar sus economías en un grado aún mayor de lo que lo hace el poder central. Por un lado está la propia afirmación de su poder, en un sistema todavía relativamente joven. [...] En otros casos, sin embargo, la regulación es el resultado de objetivos específicos, dirigidos a apoyar los intereses de determinados grupos sociales y económicos» (15).

A partir de los argumentos de Cabrillo cabría entender que, con carácter general, la regulación autonómica, aun dirigida por mayorías favorables a la liberalización de la economía y contrarias a la intervención de los poderes públicos, suele ser más proclive al desarrollo de los derechos sociales de lo que cualquier mayoría, incluso intervencionista, en el poder central. Y lo cierto es que, analizada en profundidad, esta aseveración cobra bastante sentido. Para entenderlo habría que remitirse a la distribución competencial y partir del contexto político en el que $-y$ para el que - se crea el Estado de las Autonomías.

A diferencia de otros modelos compuestos o federales, como el alemán o el de los Estados Unidos, que son tendencialmente simétricos, el Estado compuesto español se asienta sobre una tensión entre los poderes "central» y "periféricos», que viene motivada por factores históricos, lingüísticos o económicos de gran calado. Álvarez, Portos y Vourdas definen la "distancia cultural» como la relación entre las culturas central del Estado y periféricas. A través de cálculos econométricos hallaron la relación de este factor con la formación de mayorías electorales centrífugas en determinadas regiones europeas (16). Son, precisamente, estas mayorías electorales las responsables del desarrollo legislativo de las medidas administrativas que aquí analizamos. Podemos hablar, por tanto, de un punto de conexión entre las tensiones culturales y la evolución de la legislación en materia de vivienda y protecciones sociales.

Siguiendo con esta tesis, cuando analizamos la distribución de los títulos competenciales comprobamos que, mientras que al Estado le fueron

(15) CABRILLO RODRÍGUEZ, "Unidad de mercado y competencia regulatoria», Op. cit., págs. 29-30

(16) Cfr. ÁLVAREZ PEREIRA, Brais, PORTOS, Martín y VOURDAS, John, «Waving goodbye? The determinants of autonomism and secessionism in Western Europe» en Regional Studies, 2017, pág. 4 
atribuidas competencias relativas a aspectos más nucleares de la economía, tales como: la determinación de las bases y coordinación de la planificación general de la actividad económica o la determinación de las bases del sector energético; a las Autonomías les fueron atribuidos títulos de naturaleza más prestacional o asistencial, vinculados a los denominados "derechos sociales" o cuyo desarrollo requiere de una mayor intervención de los poderes públicos en el ámbito de dichos derechos como, entre otros, la vivienda.

Teniendo en cuenta que existe una tensión evidente entre el Estado y las Comunidades Autónomas, el hecho de que el marco de operaciones de estas últimas sea, fundamentalmente, el de los derechos y las protecciones sociales resulta determinante, pues su desarrollo es la única manera que las Autonomías tienen de resolver dicha tensión.

Es normal, por tanto, que en la actualidad haya cierta identidad entre centralización y políticas de laissez faire por parte del Estado y descentralización y desarrollo de políticas proteccionistas de la mano de las Autonomías. No parece que se trate solo de una opción, sino de un resultado inevitable.

\section{Reino Unido y Escocia: La exigibilidad del derecho en el marco internacional}

En el ámbito comparado encontramos ciertas equivalencias que nos permiten contrastar de algún modo esta tesis. Cuando Keating estudia el proceso de descentralización desarrollado en Gran Bretaña a finales de los 90' nos informa de que, en los años posteriores a la devolution, aunque hubo gobiernos laboristas tanto en Londres como en Edimburgo que mantenían líneas políticas similares, "Escocia no siempre siguió al Reino Unido en el programa de externalización y mercantilización del sector público» (17).

Los críticos con la descentralización, normalmente, denuncian el riesgo de que se produzca lo que técnicamente la literatura denomina "carrera hacia el fondo", por la potencial competencia entre las administraciones. Es decir, que las previsiones sociales se vean mermadas en el marco de una competencia interregional que rebaje impuestos y prestaciones a cambio de que las empresas se alojen en su territorio. A esto hace referencia, entre los académicos españoles, el propio Cabrillo(18). Respecto del caso escocés, Keating opone, de manera interesante, el hecho de que, sin embargo, en la práctica, la descentralización en el Reino

(17) KEATING, Michael, "The political economy of devolution» en A Wealthier, Fairer Scotland. The Political Economy of Constitutional Change. Edinburgh University Press. Edimburgo, 2017, pág. 13

(18) Cfr. CABRILLO RODRÍGUEZ, "Unidad de mercado y competencia regulatoria», Op. cit., pág. 31 
Unido no ha producido otra cosa sino una "carrera hacia arriba", al haberse encargado las administraciones descentralizadas de «ampliar universalidades y derechos sociales» (19).

Aunque no cuenten con Constitución escrita, el sistema de descentralización británico, basado en la atribución de títulos competenciales, recuerda al sistema de descentralización español. Su ordenamiento también ha atribuido a las regiones el desarrollo del derecho de vivienda $y$, a este respecto, resulta interesante observar como el derecho a la vivienda en Escocia tras la devolution, no solo tiene una cobertura mayor que el previsto en el resto de la Unión, sino que además destaca en el ámbito comparado por sus innovaciones.

La 2012 Commitment escocesa, elaborada en el marco de la Homelessness etc. (Scotland) Act ha superado los estándares fijados en el derecho británico anterior a la descentralización al haber prescindido de los filtros para la concesión de ayudas fundados en la "prioridad», universalizando, así, las prestaciones en materia habitacional (20).

El derecho inglés - Inglaterra no tiene parlamento propio, por lo cual su legislación depende íntegramente de lo decidido en Westminster - dispone de una herramienta denominada Empty Dwelling Management Order (EDMO), que se asemeja a la norma andaluza en materia de vivienda por su contenido y efectos. Sin embargo, lo cierto es que los resultados de este instrumento administrativo son muy pobres, apenas se llevó a efecto 17 veces en todo 2014, frente a un parque de 600.000 viviendas vacías (21).

En Francia, aunque el derecho a la vivienda no llega a reconocerse constitucionalmente(22) existe la llamada Ley DALO (Droit au logement opposable) que produce unos efectos similares a los instrumentos referidos y que, como en el caso de las EDMO, tampoco ha tenido gran alcance en la práctica.

En opinión de Eleta-De Filippis (23), que elaboró un estudio práctico de la tramitación de los recursos franceses: «opera en la práctica una jerarquización de los solicitantes prioritarios y urgentes alrededor de criterios

(19) Cfr. KEATING, Op. cit., pág. 9

(20) Cfr. KING, Fiona, "Scotland: Delivering a Right to Housing", en Journal of Law Social Policy núm. 24, 2015, págs. 156 y 161

(21) Cfr. OSBORNE, Hillary, "Powers to bring empty houses into use "ignored" " en The Guardian, 11 de febrero de 2015 [Consultado en línea el 9 de junio de 2017 en https://www.theguardian.com/ money/2015/feb/11/powers-empty-houses-ignored-empty-dwelling-management]

(22) Si bien es cierto que su carácter constitucional fue admitido por el Conseil constitutionnel por medio de una interpretación del Preámbulo de la Constitución de 1946. Vid. JARIA I MANZANO, Op. cit., 2011, pág. 57

(23) Cfr. ELETA-DE FILIPPIS, Roxanna, «EI derecho a la vivienda en Francia: La Ley Dalo (droit au logement opposable) actores y prácticas: Una observación de terreno" en Derecho y cambio social núm. 24, 2011, pág. 9 
morales más que legales [...] que sirvan para separar los "buenos pobres" de los "malos pobres" ". El escaso impacto de este instrumento derivaría precisamente de esa jerarquización.

Habida cuenta de todo esto y sin entrar a valorar detalladamente el impacto de la apuesta escocesa, sí podemos afirmar que, en términos de desarrollo normativo, el legislador de Edimburgo ha profundizado no sólo más que el de Londres sino también que el de otros Estados europeos. Esta profundización ha sido posible gracias a un marco de descentralización amplio que permite la generación de distintas respuestas con bases ideológicas diferentes.

En España, dichas diferencias podrían verse suprimidas de nuestro ordenamiento si la tesis actual del Constitucional - analizaremos en profundidad en el capítulo cuarto - se mantiene. La descentralización comporta una democratización del desarrollo normativo, generando ya -en nuestro ordenamiento y en los vecinos - normas más protectoras, pero, además, más eficientes y fácilmente ejecutables. Razón por la cual algunos autores, como Pisarello o Aparicio (24), apuestan por la reformulación del modelo actual, en la dirección de un "constitucionalismo multinivel» o "constitucionalismo en red» que diese más protagonismo a los diferentes agentes que operan en el desarrollo normativo del Estado.

\section{Acción pública y soluciones coactivas. La respuesta del legislador autonómico a la situación de emergencia habitacional}

\section{Las reformas autonómicas de 2013}

Como tuvimos ocasión de mencionar en el epígrafe anterior, en el 2013 se inició una ola de reformas autonómicas en materia de vivienda, eminentemente subjetivadoras del derecho, cuyo objeto es atender las necesidades habitacionales provocadas por la crisis financiera e inmobiliaria. Se trata del Decreto-ley 6/2013 de Andalucía, la Ley 24/2013 de Navarra, la Ley 2/2014 de Canarias, la Ley 3/2015 de Euskadi, la Ley 24/2015 de Cataluña, la Ley 10/2016 de Aragón, la Ley 2/2017 de Valencia y la ley 2/2017 de Extremadura. Todos estos textos fueron recurridos por el Gobierno del Estado ante el Tribunal Constitucional salvo el valenciano y el extremeño(25). No obstante, por el momento el Tribunal solo se ha pro-

(24) Cfr. APARICIO WHILELMI, Marco y PISARELLO, Gerardo, "El reconocimiento de derechos, deberes y principios en los Estatutos de Autonomía: ¿hacia una comprensión multinivel o en red de la protección de los derechos?» en El clip, núm. 42, 2007, pág. 4

(25) Al momento de realizarse este trabajo el Gobierno inició los trámites para una Comisión Bilateral con la Comunidad Valenciana, paso previo a la interposición de un recurso de inconstitucionalidad. 
nunciado sobre el Decreto-ley 6/2013, declarando inconstitucional y derogando parte de su articulado.

Las reformas se caracterizan por definir la función social de la propiedad en relación con el derecho de vivienda, sancionando a los propietarios que mantienen los inmuebles desocupados. Una determinación de los límites de la propiedad sobre la vivienda que ya había introducido en nuestro ordenamiento el art. 42 de la Ley catalana 18/2007 cuando disponía en su apartado sexto que "la Administración puede declarar el incumplimiento de la función social de la propiedad y acordar el alquiler forzoso de la vivienda». Este alquiler forzoso se articulaba mediante una expropiación temporal y de uso de los inmuebles deshabitados, de manera similar a la configurada en la presente ola normativa, si bien fue derogado por una ley posterior, la catalana 9/2011 de 29 de diciembre

Siete de los ocho textos aprobados a partir de 2013 contemplan la expropiación forzosa como la herramienta principal de la que se valen para dotar de contenido subjetivo al derecho. La única norma que no lo hace es la Ley 24/2015 de Cataluña, quizás debido a que el legislador catalán renunció, motu propio, a utilizar este procedimiento con la reforma efectuada por medio de la Ley 9/2011 (26). No obstante, el procedimiento elegido por la ley 24/2015, aunque excluye la expropiación y, en su lugar, recurre a un sistema sancionador, recuerda bastante en la práctica a los sistemas expropiatorios recogidos en los restantes textos.

En cualquier caso, estas leyes no son las primeras en vincular el derecho de vivienda con la institución de la expropiación forzosa. El art. 155.2 de la Constitución de Weimar de 1919, que ofrece la primera referencia al derecho en el constitucionalismo de Europa occidental(27), ya los conectaba cuando disponía que "[I]os bienes inmuebles cuya adquisición se necesita para satisfacer la necesidad de vivienda [...] pueden ser expropiados"(28). Así mismo, como hemos visto, otros ordenamientos vecinos como el francés, el inglés y el escocés cuentan con instrumentos administrativos de características semejantes a los que han desarrollado los legisladores autonómicos desde 2013, como la Empty Dwelling Management Order contenida en la Housing Act de 2004 para Inglaterra y Gales o la Ley DALO (Droit au Logément Opposable) de 2007 en Francia.

(26) Es necesario destacar que, pese a tener un contenido muy similar al de los procedimientos integrados en las leyes aprobadas a partir de 2013, el art. 42 de la Ley 18/2007 de Cataluña no fue recurrido ante elTC en todo su periodo de vigencia.

(27) Cfr. JARIA I MANZANO, Op. Cit., pág. 55

(28) El tenor literal del precepto es: «Grundbesitz, dessen Erwerb zur Befriedigung des Wohnungsbedürfnisses, zur Förderung der Siedlung und Urbarmachung oder zur Hebung der Landwirtschaft nötig ist, kann enteignet werden. Die Fideikommisse sind aufzulösen.» 
Las reformas autonómicas de 2013 , no obstante, sí son pioneras en el ámbito comparado por cuanto introducen una nueva vertiente del derecho subjetivo a la vivienda: el derecho de permanencia. Hasta ahora esta solo se recogía en la jurisprudencia del Tribunal Europeo de Derechos Humanos(29), el Decreto-ley 6/2013 abrió el camino a su codificación en textos legales. Bajo la forma de la expropiación temporal de uso, el legislador autonómico pretende impedir que determinadas personas, consideradas vulnerables, se vean privadas de sus viviendas, retardando materialmente los efectos del lanzamiento, otorgándoles, de este modo, un derecho de permanencia.

Los textos son tan semejantes en cuanto a su contenido que podemos abordar el estudio de sus principales características de manera conjunta. Distintos factores - como ha sido el propio sentido del fallo del Tribunal Constitucional sobre el Decreto-ley 6/2013 - han condicionado el desarroIlo, marcando ciertos cambios en las normas que nos llevan a agruparlas, principalmente, en tres generaciones normativas.

\section{Asiento de la reforma autonómica: Decreto-ley 6/2013 de Andalucía, Ley 24/2013 de Navarra y Ley 2/2014 de Canarias}

Promulgadas entre 2013 y 2014, estas reformas son la primera aproximación del legislador autonómico al desarrollo de los límites a la propiedad sobre la vivienda introducidos por el art. 42 de la Ley 18/2007 de Cataluña. Regulan una serie de categorías que reproducirán, después, las siguientes generaciones y que forman la columna vertebral de esta ola normativa. Consisten, fundamentalmente, en actuaciones de fomento para la intervención en el mercado inmobiliario y en el establecimiento de un sistema sancionador y expropiatorio que pretenden servir de garantía del derecho subjetivo a la vivienda en sus vertientes de permanencia y acceso.

La aplicación de estas medidas requiere, en primer lugar, la configuración "del supuesto de hecho al que se vincula el incumplimiento de la función social»(30), es decir, la determinación del concepto jurídico de "vivienda deshabitada». Los legisladores autonómicos lo hicieron mediante una definición básica del hecho y la enumeración numerus apertus

(29) Caso Marzari vs. Italia, donde el Tribunal falló en favor de una persona con una discapacidad física sobrevenida que fue desalojada de su vivienda por haber dejado de pagar el alquiler como medida de presión para que reformasen el inmueble en que residía a fin de adaptarlo a las necesidades derivadas de su estado.

(30) TORNOS MAS, "Las viviendas desocupadas y la función social de la propiedad», Op. cit. pág. 161 
de una serie de indicios objetivos de no habitación. Esta categoría se acompaña de la obligación de colaboración para todas las personas físicas y jurídicas con la Administración, a fin de proveerla de la información necesaria para la declaración de las viviendas deshabitadas.

La declaración se realiza por medio de un procedimiento contradictorio con trámite de audiencia y con un plazo máximo de resolución de un año. Finaliza con una resolución declarativa que se lleva a inscripción - de oficio - a un Registro de viviendas desocupadas, creado a partir de estas mismas normas.

Las reformas dan cuerpo a la nueva función social de la propiedad a través de un sistema de infracciones entre las que destaca la de no dar efectiva ocupación a los inmuebles destinados a servir de vivienda durante el plazo de dos años para el caso de que el propietario sea una persona jurídica. En las fórmulas andaluza y canaria las sanciones correspondientes a estas infracciones son multas pecuniarias, sin embargo, la norma navarra contempla, además, en su art. 52, la expropiación forzosa del inmueble como sanción complementaria. Está prevista frente al incumplimiento de las sanciones ordinarias, o de un requerimiento de ocupación.

Con todo, el aspecto más contestado de estas normas, que constituye el núcleo de los recursos de inconstitucionalidad es la «Declaración del interés social a efectos de expropiación forzosa de la cobertura de necesidad de vivienda de personas en especiales circunstancias de emergencia social». Ésta define un procedimiento expropiatorio con el que pretende desarrollar el sentido subjetivo de permanencia del derecho a la vivienda.

Dada la actual situación económica y las condiciones del mercado de vivienda, el desalojo de estas personas consideradas "vulnerables», podría llevarlas a una permanente situación de falta de hogar, al no hallarse en situación para afrontar el coste de un nuevo inmueble. Sin embargo, resulta llamativo que este procedimiento no busca solo mantener a las personas en una vivienda, pues esta finalidad podría conseguirse con el mero realojo en otra finca, sino que busca mantenerlas en el que había venido siendo su hogar hasta ese momento. Algo que parece partir de un concepto amplio de vivienda, que algunos autores como Ponce(31) conciben como el «espacio propio donde poder desarrollar la intimidad y la vida familiar».

(31) Cfr. PONCE, Juli, "Siete consideraciones sobre el derecho a la vivienda, la ciudad y las viviendas vacías: podemos hacer más (y mejor)." en Revista catalana de dret públic blog, 2015 [Consultado en línea el 23 de julio de 2017 en https://eapc-rcdp.blog.gencat.cat/2015/03/20/sieteconsideraciones-sobre-el-derecho-a-la-vivienda-la-ciudad-y-las-viviendas-vacias-podemos-hacermas-y-mejor-juli-ponce-sole/] 
La expropiación es de uso y temporal(32) de las viviendas objeto de un procedimiento de ejecución hipotecaria que fueron propiedad de personas consideradas vulnerables y cuyo adjudicatario final es una entidad financiera o sus filiales inmobiliarias y entidades de gestión de activos. La causa expropiandi es el incumplimiento de la función social de la propiedad que introducen las normas.

La expropiación se aplica una vez producido el efectivo traslado de propiedad entre ejecutado y ejecutante y busca mantener durante tres años al desahuciado en posesión del inmueble en condición de usuario. Las características básicas de esta expropiación, la temporalidad y la parcialidad - solo se expropia el derecho de uso-, llevan a Moreu a entender que se trata en realidad de un alquiler forzoso(33) algo que encaja con el hecho de que ya en la norma catalana de 2007 se configurase expresamente como un alquiler forzoso en el propio texto.

La legislación estatal en materia de expropiación forzosa establece que el abono del justiprecio le corresponde al beneficiario de la expropiación. Dado que el beneficiario aquí es una persona en situación de vulnerabilidad, pudiéndose encontrar este ante la paradoja de verse obligado al pago de una cantidad que no fuese capaz de soportar económicamente, las leyes autonómicas recogen un régimen especial en el que participa la Administración. Así, el beneficiario solo queda obligado al pago de una cantidad reducida que no puede ser superior al $25 \%$ de sus ingresos ni superior al total del propio justiprecio.

Un problema de orden práctico deriva de este sistema mixto ya que, en esta primera generación normativa, los textos condicionan el pago a las disponibilidades presupuestarias. Esto pone en cuestión la aplicación práctica del procedimiento, pues sin pago del total del justiprecio no puede llevarse a efecto la expropiación. La norma andaluza prevé un fondo construido a partir de la remuneración procedente de los intereses devengados en los depósitos por fianza de arrendamiento y suministro de la Comunidad, sin embargo, en opinión de Díaz(34) estos fondos en 2012 no excederían de unos hipotéticos $800.000 €$, a todas luces insuficientes para afrontar una medida de estas dimensiones.

Las normas no recogen en ningún apartado la cantidad a entregar en concepto de justiprecio, sino que se remiten a la legislación estatal. A partir

(32) El decreto andaluz y la ley canaria establecen un máximo de tres años para la expropiación y la ley navarra sube este plazo a los cinco años.

(33) Cfr. MOREU CARBONELL, Elisa, "Sanción y expropiación de viviendas deshabitadas por incumplimiento de su función social o en circunstancias de emergencia social» en Vivienda y crisis económica. Estudio jurídico de las medidas propuestas para solucionar los problemas de vivienda provocados por la crisis económica. Cizur Menor. Navarra, 2014

(34) Cfr. DÍAZ CADÓRNIGA, Jorge, "Decreto-ley andaluz 6/2013 sobre viviendas: ¿un adecuado instrumento de política social?» en El notario del siglo XXI núm. 67, 2013 
de esta remisión, partiendo del art. 42 de la Ley de la expropiación forzosa que nos envía a las reglas de valoración de la Ley del impuesto de transmisiones patrimoniales y actos jurídicos documentados, Moreu (35) calcula el montante total en un $2 \%$ por cada período de un año sobre el $75 \%$ del valor de la vivienda según la tasación que conste en el contrato hipotecario.

Finalmente, en todo caso, podemos cuestionar que el legislador autonómico haya optado por establecer esta garantía por medio de la institución, pues aún en su modalidad de urgencia resulta un procedimiento engorroso y lento, poco práctico de cara a una medida que se presenta como una respuesta a una situación de "emergencia social».

\section{Acción pública y grandes propietarios: Las leyes 3/2015 de Euskadi y 24/2015 de Cataluña}

Esta segunda generación normativa mantiene las mismas características que comentamos respecto de la primera, introduciendo algunas variaciones innovadoras, entre las que destacan el reconocimiento, en la ley vasca, de una acción pública para demandar la asignación de una vivienda, o el desarrollo en la Ley 24/2015 de Cataluña del concepto jurídico de "grandes propietarios" y de un sistema de alquiler forzoso que prescinde de la expropiación.

La primera acción pública reconocida en nuestro ordenamiento para ejercitar el derecho de habitación es la del art. 6 de la Ley catalana de vivienda 18/2007. Sin embargo, esta acción no otorga ningún derecho concreto ni se acompaña de procedimiento especial alguno. Se limita a reconocer, con carácter genérico, la exigibilidad de "la legislación en materia de vivienda" ante la Administración Pública y los Juzgados de lo contencioso-administrativo. La acción pública que recoge la ley vasca (art. 6 a 9 de la Ley 3/2015 de Euskadi), en cambio, reconociendo la exigibilidad de la legislación en materia habitacional ante la Administración y los tribunales, integra, asimismo, un derecho y un procedimiento especial para demandar, ante estos mismos órganos, el concreto acceso a la «ocupación legal de una vivienda o alojamiento protegido».

Frente a la naturaleza eminentemente instrumental del art. 6 de la ley $18 / 2007$, el correlativo de la ley de vivienda Euskadi se presenta como un precepto tanto instrumental como substantivo. El componente subjetivo de la acción catalana se ve superado, entonces, en la acción de la ley $3 / 2015$, que articula por primera vez en nuestro ordenamiento, no solo la exigibilidad del derecho de vivienda sino, también, la exigibilidad de "una vivienda» conforme a la literalidad del art. $47 \mathrm{CE}$.

(35) Cfr. MOREU CARBONELL, Op. cit., págs. 409-411 
Toda persona con vecindad administrativa vasca puede ejercitar esta acción con independencia de su nacionalidad, siguiendo así las modernas tendencias universalizantes de los títulos sociales. En cuanto a los restantes requisitos subjetivos, la ley se remite a un reglamento que, al momento de escribirse este trabajo, se encuentra en desarrollo. En todo caso, su ámbito subjetivo está limitado, fundamentalmente, a personas en situación de exclusión que no vieron atendidas sus necesidades habitacionales mediante otras políticas de vivienda previstas en la legislación.

Otra de las características más interesantes de esta acción se halla en el art. 9, que habilita a la Administración para que, con carácter subsidiario, dé cumplimiento al derecho no mediante la entrega efectiva de un inmueble sino por medio de la entrega de una prestación económica equivalente. Para Maguregui, el hecho de que la ley vasca recoja esta prestación sustitutoria desplaza la acción de la materia habitacional a la materia asistencial (36), condicionando así el carácter más esencial del contenido subjetivo. Sin embargo, considerando que esta prestación se articula solo de manera subsidiaria, puede entenderse, en realidad, como una garantía de que la Administración cumplirá con su obligación, con independencia de que la Comunidad Autónoma disponga o no del suficiente parque de vivienda y, por tanto, podría resultar incluso un refuerzo de la subjetivación del derecho.

En todo caso, la ley 3/2015 también resulta innovadora más allá de esta acción por cuanto resuelve el problema referido al pago del justiprecio que se daba en las normas de primera generación. Como ya comentamos, estas lo condicionan a la disponibilidad presupuestaria lo que, de no realizarse la consignación necesaria, pondría en peligro la ejecución del procedimiento o el pago de la indemnización, generando una grave inseguridad jurídica. La ley vasca, en cambio, lo soluciona disponiendo la creación de un fondo al que asigna una cantidad concreta de dinero «equivalente al número de lanzamientos realizados en la Comunidad en procesos de desahucio por ejecución hipotecaria en el ejercicio inmediatamente anterior».

Por su parte, la ley catalana destaca por el desarrollo del concepto de gran tenidors (grandes propietarios) que se reproduce, posteriormente, en las normas de la tercera generación y sobre el que pivota un sistema alternativo de intervención sobre el derecho de propiedad. El legislador catalán consigue en la práctica unos resultados muy similares a los de las restantes normas autonómicas, si bien acude como instrumento coactivo, al procedimiento sancionador. Su sistema consiste en la imposición, a de-

(36) Cfr. MAGUREGUI, Íñigo, "El derecho subjetivo de acceso a la vivienda. Reflexiones» en Urbaniker, 2015 [Consultado en línea el 30 de julio de 2017 en http://urbaniker.net/?p=841] 
terminados sujetos que son destinatarios finales de un inmueble-vivienda, previa interposición de una demanda de desahucio, la obligación de formular una oferta de alquiler social al ejecutado, bajo pena de sanción pecuniaria.

Los sujetos obligados son, por una parte, aquellas personas jurídicas que hubiesen adquirido una vivienda procedente de un procedimiento de ejecución hipotecaria después del 30 de abril de 2008 y, por otra parte, los grandes propietarios. La ley encaja en este nuevo concepto jurídico a todas las entidades financieras, sus filiales inmobiliarias y los fondos de inversión, así como a todas aquellas personas jurídicas titulares de una superficie habitable de más de 1.250 metros cuadrados, con la excepción de las que participen de la ordenación del alquiler social con un porcentaje determinado de su parque, así como los promotores de vivienda social.

Al igual que las restantes normas, para la determinación de los beneficiarios de esta medida, la ley catalana establece unos umbrales de ingresos (37). Sin embargo, a mayores, introduce en el apartado 11 del artículo 5 una cláusula que permite que también las personas que superen dichos umbrales puedan acogerse a la medida cuando medie un informe favorable de los servicios sociales que acredite una situación de riesgo inminente de pérdida de vivienda. Esta cláusula resulta innovadora en términos de universalización del derecho, en la línea de la legislación escocesa, al flexibilizar el tradicional sistema de umbrales con la entrada en la valoración de otros criterios subjetivos, pero no discrecionales. En todo caso, cualquier persona que desee acogerse a las medidas debe inscribirse en el Registro de solicitantes de habitatge.

La ley 24/2015 produce sus efectos con carácter previo al inicio del procedimiento de ejecución hipotecaria, pues la oferta del alquiler social debe formularse antes de interponer la demanda de desahucio, mientras que las medidas expropiatorias de las restantes normas autonómicas producen sus efectos una vez completado el procedimiento ejecutivo. Esta cuestión cronológica puede ser relevante en la resolución del recurso por el Tribunal Constitucional, pues, como veremos más adelante en mayor profundidad, su fallo gira entorno a la idea de superposición entre la norma autonómica de vivienda y la prórroga concedida en casos similares en la Ley estatal 1/2013

Finalmente, es necesario resaltar que al igual que la ley navarra, los instrumentos catalán y vasco comprenden mecanismos administrativos para la incorporación de vivienda vacía al parque público. La ley vasca lo hace por medio de un procedimiento expropiatorio, preceptuado en su

(37) Si bien en la ley catalana no se utilizan como referencia los múltiplos del IPREM sino los del Indicador de Renda de Suficiència de Catalunya. 
art. 59, que puede ser decretado tanto por la localidad como por la Comunidad Autónoma por un plazo máximo de cinco años prorrogables en otros cinco. Los sujetos pasivos no son descritos en el precepto así que debemos remitirnos al art. 56, donde se describe la vivienda deshabitada, comprendiendo un gran abanico de posibles titulares dominicales, excluyendo solo a los propietarios de segundas viviendas o determinados casos justificados. La ley catalana, por su parte, recurre al sistema sancionador y en su art. 7 se vale de una cesión obligatoria, imponible por un plazo máximo de tres años. El sujeto pasivo en el caso catalán se restringe a las personas jurídicas sometidas al impuesto de viviendas vacías no exentas que posean fincas desocupadas en lo que la ley denomina "zonas de fuerte y acreditada demanda residencial», es decir, zonas en que resida como mínimo una persona en situación de exclusión y de riesgo de pérdida de vivienda.

\section{Las reformas tras la respuesta del Tribunal Constitucional: Las leyes 10/2016 de Aragón, 2/2017 de Valencia, 2/2017 de Extremadura y el proyecto de ley balear}

El 14 de mayo de 2015 se publica la STC 93/2015 que resuelve el recurso interpuesto contra el Decreto-ley andaluz 6/2013, declarando la inconstitucionalidad del procedimiento expropiatorio y de varios preceptos que también regulan la intervención sobre la propiedad de inmuebles-vivienda. A partir de este momento apreciamos un cambio en el comportamiento del legislador autonómico, motivado, probablemente, por el sentido de dicho fallo. No obstante, el sentido del cambio no ha sido unívoco, y las tres leyes promulgadas hasta el momento (38) construyen respuestas divergentes. En primer lugar, se aprueba la Ley 10/2016 de Aragón, más cautelosa en el desarrollo de los mecanismos de intervención pública que las anteriores reformas y, posteriormente, las 2/2017 de Valencia y 2/2017 de Extremadura que, por el contrario, continúan la línea de las generaciones normativas precedentes.

Las tres reformas son fácilmente encuadrables como parte de esta ola normativa. La aragonesa y la valenciana reproducen el concepto de «gran tenidors" introducido en la ley catalana de 2015 si bien lo definen de manera distinta. Asimismo, en las tres leyes se formula - con mayor o menor alcance - una exigibilidad de la legislación habitacional y todas ellas intervienen en el mercado de la vivienda para garantizar el mínimo vital

(38) Aunque las leyes vasca y catalana se promulgaron con posterioridad a la publicación del fallo, dada la inmediatez con que se sucedió, la conocida lentitud del procedimiento legislativo nos hace dudar del impacto real que la sentencia haya podido tener sobre su desarrollo. 
en casos de personas afectadas por procedimientos de desahucio. Sin embargo, su aproximación es completamente diferente.

La ley valenciana integra gran parte de las innovaciones que la ola de reformas ha venido desarrollando. Por ejemplo, su sistema de intervención en el mercado consiste en una combinación entre el sistema sancionador catalán y la expropiación forzosa y viene complementado, además, por el reconocimiento de una acción pública para exigir de manera efectiva una vivienda.

Dicho sistema mixto se estructura en los artículos 12 y 13 de la ley. El primero de los preceptos desarrolla la medida sancionadora, de un contenido materialmente muy similar al sistema catalán, si bien en este caso el mecanismo se activa ya iniciado el procedimiento de ejecución hipotecaria que motiva la medida, a diferencia del catalán, que es previo. Según el artículo 12.1, "[I]a iniciación del procedimiento, judicial o extrajudicial, para la ejecución de las garantías hipotecarias [...] implicará la creación de una nueva obligación entre la entidad financiera, la filial inmobiliaria o entidad de gestión de activos que resulte adjudicataria del remate y el propietario comprador y deudor, y quedará constituido el derecho de este último a poder contratar un arrendamiento con opción de compra que evite el lanzamiento de esta vivienda».

El incumplimiento de esta obligación causa la expropiación forzosa del usufructo del inmueble en cuestión, según nos informa el art. 12.4 de la ley. Por tanto, la sanción no tiene carácter pecuniario, como sucede en el caso catalán, sino que sirve de puente entre las dos fases de este sistema mixto, activando un procedimiento expropiatorio construido a imagen de los desarrollados por las restantes reformas autonómicas. Respecto a este procedimiento, debemos señalar que se trata de una expropiación de usufructo y no de simple uso, como hasta ahora se venía contemplando y, así mismo, también destaca el hecho de que se dispone para un plazo superior al previsto hasta ahora: tres años prorrogables por otros tres años más.

El fallo del Constitucional que derogaba el procedimiento expropiatorio andaluz se sostenía, entre otros motivos, sobre una lectura en términos de compatibilidad entre la ley estatal 1/2013 y la disposición impugnada, entendiendo que esta se solapaba por sus efectos con la primera. Por este motivo, parece introducir el legislador valenciano, al comienzo del artículo 12, el siguiente tenor: "En caso de que tengan concedidas medidas estatales de moratoria, podrán acogerse a esta ley cuando finalice la mencionada moratoria».

La acción pública declarada en la reforma valenciana se articula de una manera similar a la de la ley vasca, profundizando en el desarrollo del aspecto subjetivo del derecho. No obstante, resulta llamativo que el instrumento de Les Corts contempla el silencio administrativo positivo 
como una posible forma de finalización del procedimiento. Así, el art. 6.3 establece que "[s]i transcurrido el plazo de seis meses previsto en el apartado anterior [...] no se hubiera dictado resolución, se entenderá otorgado el uso de un alojamiento por silencio administrativo". Resultando que, a diferencia de la ley $3 / 2015$ de Euskadi, ésta no contempla una prestación económica sustitutoria y, destacando el parque público de vivienda en España por su escasez, parece cuestionable la introducción del silencio positivo. Al ser recurrible ante la jurisdicción ordinaria la resolución de la Administración Pública, se corre el riesgo de generar un alto número de resoluciones materialmente inejecutables que atasquen el sistema.

La ley extremeña parece más contenida en el desarrollo del sentido subjetivo del derecho, pues no incorpora una acción pública, como hace la valenciana (39). Como sistema de intervención en el mercado se decanta por el procedimiento expropiatorio, complementado con algunas medidas sancionadoras, en la línea de la primera ola de reformas normativas, aunque como la norma valenciana, ésta prevé la expropiación del usufructo de la vivienda y no del simple uso.

Es interesante señalar que también su desarrollo parece estar condicionado por el sentido del fallo de la STC 93/2015. La norma extremeña integra en el procedimiento una cláusula condicional que parece tratar de sortear un eventual fallo derogatorio del Constitucional. Según el apartado segundo del art. 2 de la ley, la medida expropiatoria no se aplica cuando se acredite que la entidad ha concertado un alquiler asequible con el titular de la vivienda objeto de ejecución por un mínimo de tres años o, cuando "se acredite que el lanzamiento ha sido suspendido por aplicación del Real Decreto Ley 6/2012, de 9 de marzo, o la Ley 1/2013 de 14 de mayo, de medidas para reforzar la protección a los deudores hipotecarios, reestructuración de deuda y alquiler social».

Además, la ley extremeña, al igual que la norma catalana, prevé en el inciso final del artículo 2.3.c).2. ${ }^{\circ}$ que, aquellos sujetos que superen los umbrales de ingresos establecidos para la aplicación del procedimiento de expropiación forzosa, si media informe de los servicios sociales que acredite una situación de riesgo de exclusión residencial, pueden ser beneficiarios de la medida.

La ley aragonesa se aproxima a esta cuestión de una manera diferente. Dispone en su art. 19 una "garantía del derecho a una alternativa

(39) No obstante, la asamblea extremeña ha aprobado la Ley $7 / 2016$, de 21 de julio, de medidas extraordinarias contra la exclusión social que prevé, en su artículo 18, una «línea de ayudas para familias afectadas por ejecuciones hipitecarias". En virtud de este precepto, aquellas personas que pudiesen ser beneficiarias de la asignación de una vivienda de promoción pública, tendrían derecho a una prestación pecuniaria para hacer frente al pago del alquiler de una vivienda libre mientras no se resuelva la entrega de una vivienda de promoción pública 
habitacional digna", aparentemente oponible ante la Administración Pública. Sin embargo, no articula un procedimiento a esos efectos, ni tampoco es clara en la dicción sobre el carácter de este derecho ni se contempla expresamente su exigibilidad en el precepto.

En todo caso, esta ley 10/2016 de Aragón incluye muchos de los elementos presentes en leyes precedentes como el concepto de "grandes propietarios" - aunque formulado en términos diferentes a las leyes catalana y valenciana-, la declaración de viviendas deshabitadas o la cesión de viviendas desocupadas. No obstante, aunque establece una intervención en el mercado inmobiliario en favor de las personas en situación de riesgo de exclusión perjudicadas por un procedimiento de ejecución hipotecaria en su artículo 20 , el instrumento aragonés excluye la posibilidad de un sistema sancionador o expropiatorio. Quizás buscando evitar la derogación del articulado por invadir las competencias de bases y coordinación de la economía el precepto se limita a declarar sin más la «suspensión del procedimiento".

No obstante, esto podría motivar igualmente su derogación, por afectar a las competencias estatales ex art. 149.1.6 CE en materia de legislación procesal, pues su redacción parece buscar regular directamente la organización y desarrollo del procedimiento de desahucio. Con todo, la precisión introducida en el art. 21.4 de la ley podría salvar el texto al disponer que "[e]xcepcionalmente y para evitar su desahucio de la vivienda habitual, la Administración autonómica podrá hacerse cargo del pago de la renta arrendaticia». Es decir, interpretados de manera conjunta, la suspensión del art, 20 no sería un mandato al poder judicial para la interrupción del proceso, sino un mandato a la Administración Pública para que esta intervenga, por ejemplo, abonando las cantidades adeudadas, a fin de interrumpir el procedimiento por las causas legalmente establecidas. No obstante, cuesta aceptar esta interpretación siendo el tenor literal de este precepto que los lanzamientos «quedarán en suspenso".

En estos momentos, además de estas dos normas, se está tramitando la aprobación en Baleares de una nueva ley de vivienda que también recoge el concepto de "grandes propietarios" y establece un sistema de intervención en el mercado inmobiliario en favor de personas en situación de vulnerabilidad afectadas por procedimientos de ejecución hipotecaria estructurado a semejanza de las reformas autonómicas aquí expuestas. En concreto, el texto se estructura de una manera muy parecida a la ley 24/2015 de Cataluña en tanto que, por un lado, aborda la cuestión de la pobreza energética $y$, por otro, excluye el procedimiento expropiatorio y dispone en su artículo 36 - de una manera más modesta que el texto catalán - un sistema de cesión obligatoria de viviendas desocupadas propiedad de los grandes tenedores. 


\section{La respuesta del Tribunal Constitucional a las soluciones autonómicas}

\section{La aproximación formal: caso de extraordinaria necesidad y límites materiales del presupuesto habilitante}

El Tribunal Constitucional, por interpelación del Ejecutivo central, respondió a esta andanza legislativa de las Autonomías con la STC 93/2015(40). Esta sentencia resuelve el recurso interpuesto contra el Decreto-ley andaluz $6 / 2013$, la primera de las reformas de la ola normativa, sin embargo, el Tribunal Constitucional no entra a valorar la constitucionalidad de las normas por su fondo, sino que se limita al análisis de aspectos, fundamentalmente, formales.

El Abogado del Estado, en representación del Gobierno, había sustentado su impugnación en los siguientes motivos: a) Falta del presupuesto habilitante para la aprobación del Decreto-ley; b) Quiebra de los límites materiales del art. 86.1 CE para los Decretos-ley; c) Discriminación inconstitucional de entidades financieras o sus filiales inmobiliarias; d) Vulneración de la competencia estatal del art. 149.1.13 CE. El Tribunal renuncia a pronunciarse sobre el tercero de los motivos y examina, únicamente, los tres restantes, destacando por realizar una aproximación expresamente formal a los dos primeros.

\section{A. El caso de extraordinaria neCESidAd}

Se discute en el primer motivo la existencia del presupuesto habilitante que requieren el art. 86.1 CE y el art. 110 del Estatuto de Andalucía para el desarrollo del Decreto-ley. El Constitucional razona la adecuación de las normas al presupuesto del art. 86.1 CE aplicando una presunción básica. Si hacemos una lectura sistemática de los preceptos, si los analizamos como parte de un instrumento más amplio, es razonable asumir que su naturaleza dependa del conjunto. Es evidente que el Decreto-ley, globalmente considerado, responde a una extraordinaria necesidad y, por lo tanto, no parece racional dudar de la adecuación constitucional de los dichos preceptos impugnados, en concreto.

A este respecto, también se presenta la problemática de la ejecución de las normas impugnadas. Sin embargo, frente a las alegaciones del

(40) Puede resultar de interés la consulta del Auto 244/2013 del Tribunal Constitucional que se pronuncian sobre el mantenimiento de la suspensión de la norma, a efectos de conocer con detalle las posiciones de las partes. Por motivos de extensión de este trabajo no podemos profundizar en su estudio, no obstante, puede consultarse en línea en http://hj.tribunalconstitucional.es/es/Resolucion/ Show/23669 
Abogado del Estado, el Tribunal afirma que, aun cuando los preceptos desarrollan una serie de procedimientos y mecanismos complejos que retrasan su ejecución, la eficacia inmediata de la norma no depende de que se lleve a efecto con mayor o menor inmediación, pues eficacia y ejecución son elementos independientes.

En el presente supuesto, la eficacia de estas medidas nace en el momento en que se aprueban como parte integrante de «un programa de acción orientado a movilizar el parque de viviendas deshabitadas" (FJ 10) y no en el momento en que estas se pudiesen ejecutar. Por lo tanto, según este razonamiento, para elTC sí estamos ante un "caso de extraordinaria necesidad» que justifica la acción normativa del ejecutivo andaluz y, esto con independencia de que el procedimiento autonómico de desarroIlo legislativo fuere más o menos rápido.

A la luz de todas estas consideraciones en el fundamento undécimo el TC realiza una aseveración que, si bien pasa un tanto desapercibida, tiene un enorme valor jurídico. Sostiene el Tribunal que, en caso de extraordinaria necesidad, las Comunidades Autónomas pueden desarrollar las medidas que consideren necesarias siempre que se hallen dentro de su espectro competencial, incluso cuando el Estado ya haya legislado la materia desde el suyo propio. Este razonamiento, que parece formularse como una concesión a los intereses del legislador autonómico, esconde realmente un claro sentido centralizador, pues no podemos entenderlo si no partimos de una prevalencia de la acción normativa del Estado en las llamadas "competencias compartidas" e, incluso, en las "competencias exclusivas" de las Comunidades Autónomas.

El vaciamiento competencial en las materias compartidas venía asentándose en la doctrina del Constitucional. Este vaciamiento se manifiesta a través de una interpretación amplia del concepto de "bases» de una manera que trasciende la noción de regulación nuclear y que alcanza tanto leyes como incluso reglamentos administrativos o actos meramente ejecutivos (41).

La novedad radica, sin embargo, en una nueva interpretación expansiva de los títulos competenciales del Estado y el impacto que ésta provoca sobre las materias exclusivas de las Comunidades Autónomas. Se trata de la construcción de una ratio particular que ya se venía gestando en pronunciamientos anteriores y que constituye el pilar fundamental de esta sentencia: el dibujo de una nueva distribución competencial.

(41) Cfr. BARCELÓ I SERRAMALERA, Mercé, "La doctrina de la sentencia 31/2010 sobre la definición estatutaria de las categorías competenciales" en Revista catalana de dret públic núm. Especial S, 2010, pág. 251 


\section{B. Los Límites materiales del PRESUPUESTO habiLITANTE. EL DERECHO DE PROPIEDAD Y EL DERECHO A LA VIVIENDA}

Podemos afirmar, en síntesis, que la norma impugnada responde a una extraordinaria necesidad $y$, por lo tanto, que existe presupuesto habilitante para la acción normativa del ejecutivo andaluz. Sin embargo, una serie de preceptos del Decreto-ley encontraría, según el Tribunal, su falta de acomodo constitucional en los límites materiales que establecen los art. 86.1 CE y 110 del Estatuto de Autonomía de Andalucía. Se trata de los art. 1.3, 25.5, 25.6 y 53.1a) del Decreto que, según la sentencia, afectarían al derecho de propiedad y, por lo tanto, contravendrían la prohibición impuesta por el dicho art. 86.1 CE al desarrollo de estas normas de no afectar a los derechos fundamentales.

Es innegable el encaje pacífico y consolidado de los preceptos referidos en el marco del art. 33 de la Constitución. Es cierto que, según la tradición jurisprudencial y doctrinal, la función social de la propiedad se configura al imponer obligaciones o condiciones al propietario en su derecho o al orientar el uso que este hace de sus bienes (42) como sucede con las normas impugnadas $y$, también, que el propio articulado hace referencia expresa al derecho de propiedad.

Aun así, toda vez que «el análisis de la problemática jurídica de la vivienda va más allá de los problemas entre la oferta y demanda de un bien que está en el mercado, de un bien a cuyo disfrute se puede acceder en condición de propietario o arrendatario, y que se puede utilizar como garantía de un crédito hipotecario" (43) parece legítimo cuestionar que esta sea la única interpretación válida. La lectura jurídica que se puede hacer de los preceptos impugnados no es unívoca y las referencias directas al acceso a la vivienda o a la habitación efectiva de inmuebles que hallamos en ellos conectan con el derecho a una vivienda digna y adecuada, preceptuado en el art. $47 \mathrm{CE}$. El artículo primero del Decreto en su apartado tercero establece una serie de medidas de fomento destinadas a favorecer el acceso a la vivienda y los artículos $25.5,25.6$ y 53.1.a) establecen las bases de un mecanismo administrativo que sanciona la no habitación de las fincas.

El Tribunal Constitucional solo reconoce la perspectiva dominical de los preceptos, por considerar que estos se limitan a establecer "que el único uso posible de un determinado tipo de bienes debe realizarse de un modo efectivo" (FJ 13). Sin embargo, esto no es del todo cierto ya que no se trata de cualquier tipo de bienes, sino de aquellos que constituyen, o

(42) Cfr. TORNOS MAS, Joaquín, "La dignidad humana y el derecho a una vivienda digna" en $E I$ Cronista del Estado Social y Democrático de Derecho núm. 61-62, 2016 pág. 32

(43) Íbid, pág. 31 
son susceptibles de constituir, domicilio habitual. Así mismo, cuando el Decreto-ley impone una modalidad de uso determinado sobre estos, tampoco está hablando de cualquier tipo de uso, sino del que afecta al propio núcleo del artículo $47 \mathrm{CE}$.

En un contexto social y económico de emergencia habitacional, en el que se reproduce un conflicto fáctico entre vivienda y mercado, la Junta de Andalucía opta por elaborar un conjunto de protecciones que, deliberadamente, desarrollan el derecho de habitación. Invirtiendo la lógica del Constitucional, podemos preguntarnos si acaso la función social de la propiedad sobre la vivienda no es, sino, parte del contenido del derecho de vivienda. A estos efectos podemos señalar el art. 3.4 del Real Decreto Legislativo $7 / 2015$, de 30 de octubre, por el que se aprueba el texto refundido de la ley del suelo y rehabilitación urbana que dispone que "[e]। suelo vinculado a un uso residencial por la ordenación territorial y urbanística está al servicio de la efectividad del derecho a disfrutar de una vivienda digna y adecuada, en los términos que disponga la legislación en la materia».

Algunos autores, así lo entienden, como Ruiz-Rico (44), para quien «[e] I derecho a la vivienda comprende implícitamente algunas dimensiones específicas. La más relevante posiblemente sea la indicación obligatoria de una función orientada a asegurar las condiciones objetivas que permitirían el ejercicio individualizado de ese derecho constitucional». En un sentido similar, Jaria i Manzano sostiene que la configuración del derecho de habitación en el bloque constitucional le otorga «al acceso a la vivienda una protección constitucional que justifica determinadas medidas tuitivas de los poderes públicos, que pueden constituirse en limitaciones a determinados derechos» (45), Ilegando, en el caso de su articulación en los Estatutos de Autonomía, a amparar "medidas que constituyan una limitación a derechos constitucionales económicos como el de propiedad o la libertad de empresa, con el objetivo de facilitar el acceso a una vivienda digna" (46). Y es que, de lo contrario se estaría vaciando de sentido el derecho a la vivienda, limitándolo a su vertiente de ordenación urbanística y del suelo.

Tampoco podemos desconocer la cláusula final del art. 47 CE que obliga a los poderes públicos a frenar la especulación sobre la vivienda. Para Ruiz-Rico esta cláusula comprende tanto el diseño de iniciativas legislativas en materia de urbanismo como, también, la creación de instrumentos y planes generales de vivienda y, en todo caso, "una habilitación

\footnotetext{
(44) RUÍZ-RICO, Op. cit., pág. 35

(45) JARIA I MANZANO, Op. cit., pág. 72

(46) Íbid, pág. 65
} 
que alcanza a la actuación administrativa de los poderes públicos» (47). Por ello, podemos preguntarnos si acaso hoy, habida cuenta de la burbuja inmobiliaria y la crisis del crédito hipotecario, el control sobre la especulación que el ejecutivo andaluz realizaba a través de la norma impugnada, no entraría también dentro del contenido de dicha cláusula y por lo tanto, dentro del contenido del derecho de habitación.

\section{CARÁcter subjetivo del DeRECho a LA ViviendA}

Ahora bien, el hecho de que podamos juzgar que los preceptos impugnados están amparados por el derecho a la vivienda no los excluye de una potencial declaración de inconstitucionalidad. El art. 110 del EAAnd establece que los Decretos-ley no podrán afectar a los derechos recogidos en el propio Estatuto. El estatuyente andaluz dispuso en su art. 25 que: "[p]ara favorecer el ejercicio del derecho constitucional a una vivienda digna y adecuada, los poderes públicos están obligados a la promoción pública de la vivienda. La ley regulará el acceso a la misma en condiciones de igualdad, así como las ayudas que lo faciliten».

Llegados a este punto, la cuestión estriba en determinar si el art. 25 del Estatuto andaluz reconoce efectivamente un derecho de habitación o no y si este es, efectivamente, un derecho o un mandato a los poderes públicos. Aquí nos encontraríamos con tres posibles interpretaciones que motivarian soluciones distintas.

Parte de la doctrina entiende que los Estatutos no pueden establecer una declaración de derechos, pues esta facultad «no está entre las materias que el art. 147.2 CE enumera como propias de los Estatutos de Autonomía» (48). Así, no podríamos entender el art. 25 del EAAnd como un derecho en sentido propio y, por lo tanto, el Decreto-ley 6/2013 no conculcaría ningún límite material para el desarrollo de estas normas.

Sin embargo, la jurisprudencia del Tribunal Constitucional sí ha reconocido a los estatuyentes autonómicos la facultad de integrar en sus textos declaraciones de derechos. Expresamente lo razona en su sentencia 247/2007, de 12 de diciembre, confirmada después por la 249/2007, de 13 de diciembre, donde dispone, a modo de síntesis, que "el contenido estatutario no puede entenderse de acuerdo con una interpretación literal del art. $147 \mathrm{CE}$, en concreto, de los cuatro subapartados relacionados en su apartado 2, puesto que el Estatuto puede regular aspectos complementarios a los señalados tanto en su dimensión material como organizativa» (FJ 5).

(47) RUÍZ-RICO, Op. cit., pág. 34

(48) DÍEZ-PICAZO, Luís María, «¿Pueden los estatutos de autonomía declarar derechos, deberes y principios?» en Revista Española de Derecho Constitucional núm. 78, 2006, pág. 65 
Ahora bien, ¿es el derecho a la vivienda un derecho subjetivo o un principio rector de la política social y económica? Según el AltoTribunal el derecho a la vivienda inscrito en el art. 47 CE se configura como un mero mandato a los poderes públicos (STC 152/1988) y, del mismo modo, el derecho a la vivienda recogido en el Estatuto andaluz, como un mandato a los poderes públicos autonómicos andaluces (STC 93/2015). No estaríamos, por tanto, ante un verdadero derecho exigible ante los tribunales, sino ante un marco de referencia para el desarrollo normativo. Si seguimos esta lectura, podríamos considerar que, por este motivo, al no afectar a un derecho, sino a un principio rector, no se contravendría el mandato del art. 110 EAAnd que sanciona el desarrollo de derechos estatutarios por el Ejecutivo. Y, por tanto, los preceptos impugnados sí serían compatibles con el bloque de constitucionalidad.

Una tercera solución se sustenta en la lectura que un sector de la doctrina hace del derecho de habitación, entendiéndolo, bien como un derecho subjetivo, bien como un derecho con potencialidad subjetiva desarroIlable por vía del art. 53.3 CE.

Así, para Ponce, el art. 47 CE se configura como un auténtico derecho subjetivo por cuanto de él se derivan obligaciones jurídicas para un sujeto en favor de otro (49). La exigibilidad directa o indirecta de este derecho, en su opinión, se comprueba en la propia jurisprudencia del Tribunal Supremo, los Tribunales Superiores de Justicia de las Comunidades Autónomas e incluso de los Juzgados de lo Contencioso-administrativa (50).

Por otro lado, Tornos entiende que el precepto constitucional, así como los derechos estatutarios en materia de vivienda son, únicamente, «mandatos de optimización" a los poderes públicos por cuanto no reconocen acción alguna. Su exigibilidad ante los tribunales resultaría determinante para su reconocimiento como auténtico derecho subjetivo $y$, por tanto, esta exigibilidad depende de su posterior desarrollo por el poder legislativo(51), sin embargo, dicho desarrollo si dotaría al derecho de un aspecto subjetivo, apartándolo de la mera consideración de principio informante del ordenamiento.

Por tanto, irónicamente, si nos guiamos por estas tesis más proactivas con las personas afectadas por los procedimientos de desahucio, el Decreto-ley si rebasaría los límites del art. 110 EAAnd por resultar un auténtico derecho con eficacia jurídica y, así, los art. 1.3, 25.5, 25.6 y 53.1a) del Decreto-ley 6/2013 resultarían incompatibles con el bloque de constitucio-

(49) Cfr. PONCE, "La tutela judicial del derecho a la vivienda y el papel del Tribunal Constitucional español: luces y sombras en el contexto europeo e internacional», Op. cit., pág. 62

(50) Íbid., págs. 51, 56 y 61

(51) Cfr. TORNOS, "Las viviendas desocupadas y la función social de la propiedad», Op. cit. págs. 149 y 150 
nalidad al afectar a un derecho - el de vivienda - recogido en el Estatuto de Autonomía de Andalucía.

\section{Un nuevo reparto competencial en materia de vivienda}

Declarados inconstitucionales los art. $1.3,25.5,25.6$ y $53.1 \mathrm{a})$, el Tribunal centra ahora su examen en la Disposición Adicional segunda y en los apartados restantes del artículo 25 del Decreto andaluz. La idea central de ese examen es determinar el ajuste constitucional de los preceptos a las reglas del juego competencial.

El marco normativo que tomaron como referencia los magistrados a la hora de evaluar la constitucionalidad de la norma andaluza es, exclusivamente, la Ley $1 / 2013$ de 14 de mayo de medidas para reforzar la protección a los deudores hipotecarios, reestructuración de deuda y alquiler social. Este texto dispone en su Capítulo I la suspensión de los lanzamientos sobre viviendas habituales de determinados colectivos vulnerables afectados por un procedimiento de ejecución hipotecaria dirigido contra la que es su vivienda habitual. Esta suspensión produce sus efectos antes de que se produzca el lanzamiento y comporta su absoluta suspensión.

Para el TC, el ejecutivo andaluz, con el desarrollo del Decreto-ley habría roto con la política estatal contenida en este marco normativo $y$, por lo tanto, habría invadido el ámbito competencial del art. 149.1.13 CE (bases y coordinación de la economía), atribuido en exclusiva al Estado. Esta invasión, según la mayoría que subscribe el fallo, se produciría por la concurrencia de tres circunstancias. La primera: que el Decreto-ley regula aspectos relevantes para el mercado hipotecario. La segunda: que ya existe regulación estatal en el ámbito de protección social que pretende desarrollar el ejecutivo andaluz y que las Comunidades Autónomas no pueden transcender esos niveles de protección. Y la tercera: que el Decreto-ley, según entiende el Tribunal, rompe con la legislación estatal, obstaculizando su aplicación.

\section{A. LA HIPÓTESIS DE LA DISTORSIÓN DEL MERCADO HIPOTECARIO}

Con el Decreto-ley 6/2013 el ejecutivo andaluz diseñó un instrumento que comprende tanto políticas de fomento en materia de vivienda como medidas que desarrollan la vertiente subjetiva de este derecho. La lectura teleológica y sistemática de la Disposición adicional segunda y del art. 25 del texto nos lleva inmediatamente al contenido del art. 47 CE. Su finalidad no es regular las necesidades de los deudores hipotecarios, sino atender a necesidades habitacionales de sectores en grave riesgo de exclusión 
social. Es innegable que estas medidas, en desarrollo del derecho de vivienda, afectan al mercado hipotecario, pero ni su finalidad principal es esa ni el nivel de incidencia es, económica y jurídicamente, relevante.

En el recurso, la Abogacía del Estado sostiene que la medida impugnada pone en riesgo el objetivo de desinversión de la Sociedad de Gestión de Activos procedentes de la Reestructuración Bancaria (SAREB), argumento que asume el Constitucional para resolver en su fallo. Sin embargo, el ámbito subjetivo del texto andaluz es tan acotado que parece cuestionable estimar dicho riesgo. La norma andaluza solo resulta aplicable a las necesidades de unidades familiares concretas que, entre otros, deben cumplir los siguientes requisitos: a) sus ingresos no superen el triple del IPREM; b) el esfuerzo que representa la carga hipotecaria sobre estos ingresos se haya multiplicado por, al menos, 1,5 puntos; y c) que este esfuerzo suponga más de un tercio de la renta familiar, proporción que destaca con el umbral, más amplio, del cincuenta por ciento previsto en la norma estatal.

Es difícil calcular con exactitud el nivel de incidencia ya que los datos no se hayan tan desagregados como sería deseable, pero sabemos que, en 2013, el Consejo General del Poder Judicial cifró en 4.280 el total de los lanzamientos practicados en Andalucía derivados de ejecuciones hipotecarias; que el gasto medio(52) en vivienda en España representaba menos del tercio de los ingresos familiares en ese mismo año; y que la renta media (53) por hogar en Andalucía estaba por encima del triple del IPREM correlativo. Sabemos, además, que la SAREB en el año 2015 ya se había desprendido de un $22 \%$ de sus activos inmobiliarios (54) y que el último censo del INE(55) sobre vivienda computaba 637.221 viviendas vacías en la Comunidad Autónoma andaluza. A la luz de estos datos, parece que hablamos, por tanto, de un instrumento con un efecto económicamente marginal, sin capacidad de alterar ningún tipo de planificación o estrategia económica, pero con una elevada potencialidad en términos humanos.

El Decreto-ley amortigua la aceleración de la incorporación de stock al mercado, al imponerles a determinados inmuebles lo que, para alguna autora como Moreu es, en realidad, un alquiler forzoso (56). Sin embargo, nada obsta para que el nuevo propietario pueda disponer de los bienes

(52) Nota de prensa del INE de 17 de junio de 2015 de la Encuesta de presupuestos familiares Año 2014. Consultada en http://www.ine.es/prensa/np914.pdf

(53) Fuente: INE

(54) Consultable en http://www.elmundo.es/economia/2015/04/01/551aec23268e3e7a288b457b.html

(55) Nota de prensa del INE de 18 de abril de 2013 de los Censos de población y viviendas 2011. Consultada en http://www.ine.es/prensa/np775.pdf

(56) Cfr. MOREU, Op. cit. 
como quiera, mientras no los ocupe en el plazo legalmente establecido. La norma habilita a la Administración andaluza, únicamente, para la expropiación temporal del derecho de uso (ius utendi), pero no del resto de facultades dominicales, ni si quiera del derecho de disfrute (ius fruendi). Aunque sí se merme parte del atractivo mercantil de los inmuebles por quedar afectos temporalmente a una expropiación de uso, no se imposibilita o condiciona su enajenación. Resulta interesante advertir en este punto que la ley marco estatal que el fallo considera afectada sí establece, en cambio, un plazo suspensivo en la ejecución que impide que la propiedad pase del ejecutado al ejecutante, obstaculizando realmente los objetivos de desinversión.

Cualquier análisis jurídico del impacto que la norma recurrida pueda generar a los objetivos de la SAREB debería estar acompañado de un estudio que lo sustente, especialmente teniendo en cuenta que esta Sociedad está participada por más de un $50 \%$ de capital privado. El Tribunal Constitucional opta, en cambio, por realizar una serie de afirmaciones apodícticas con un contraste discutible con la realidad económica sin aportar ningún estudio justificativo en la sentencia, como han señalado voces en la literatura como Ponce (57).

Se sugiere en el pronunciamiento, además, que el Decreto-ley rompe con la política de "reorganización y recapitalización del sector financiero» que desarrolló el Estado ante "la dificultad de acceso al crédito por empresas y consumidores». Es cierto que el hecho de que la norma andaluza comporta efectos desfavorables para las entidades crediticias y financieras podría suscitar en ellas un cierto recelo en la concesión del crédito, condicionando la política estatal de reflote del mercado hipotecario. Ahora bien, realizando un examen profundo, es necesario matizar esta secuencia lógica con dos precisiones.

En primer lugar, el acceso a las hipotecas debe constreñirse para prevenir la formación de nuevas burbujas y situaciones de sobre endeudamiento, cumpliendo así con el mandato de la Directiva 2014/17/EU. EI mercado hipotecario en España es un mercado sobredimensionado y deformado por una tasa de tenencia de la vivienda en propiedad que se sitúa entre el $77,3-78,8 \%$ frente a un $15,6-21,1 \%$ de alquiler (58). Esta proporción es el producto artificial de una «continuada política de estímulo a la

(57) Cfr. PONCE, Juli, «¿Ha expropiado el Tribunal Constitucional las competencias autonómicas en materia de vivienda?» en Transjus, 2015 [Consultado en línea el 12 de octubre de 2016 en https:// transjusblog.wordpress.com/2015/06/04/ha-expropiado-el-tribunal-constitucional-las-competenciasautonomicas-en-materia-de-vivienda-a-proposito-de-la-stc-de-14-de-mayo-de-2015-declarando-lainconstitucionalidad-de-la-regulacion-an-2/]

(58) La relación de 77,3 (propiedad) y 15,6 (alquiler) la proporciona el INE en su Encuesta de condiciones de vida y la relación de 78,8 (propiedad) y 21,1 (alquiler) se refleja en las Housing statistics del Eurostat. 
propiedad» (59) perfectamente comprobable en la evolución histórica recogida por el INE, según la cual, frente a la tasa del $46,9 \%$ en propiedad y $51,4 \%$ en alquiler del año 1950 , tras un crecimiento constante en las sucesivas décadas, nos encontramos ante un $77,3 \%$ y $15,6 \%$ respectivamente en el año 2015(60).

Y, en segundo lugar, no es cierto que la caída de la concesión de préstamos a la vivienda se tenga que acompañar necesariamente de una caída global del crédito. La realidad, de hecho, es muy distinta: según los actuales datos de evolución de la financiación existe una cierta relación entre el crecimiento negativo del crédito nuevo a la vivienda y el crecimiento positivo del crédito nuevo al consumo. Se aprecia el desplazamiento hacia el crédito al consumo como una especie de "vía de escape para los bancos ante las dificultades de rentabilidad en el sector» (61) que pone en cuestión la idea que parece ser la base del enjuiciamiento de constitucionalidad de que la única solución del mercado ante una situación de estrés es la salida de los competidores.

Habida cuenta de todo lo expuesto, tanto por su finalidad e impacto, como por su sistemática, cuesta creer que la Disposición Adicional Segunda y el art. 25 del Decreto-ley 6/2013 sean en realidad un instrumento de regulación del mercado hipotecario. En todo caso, los efectos colaterales sobre entidades crediticias y financieras de esta medida deben comprenderse dentro del ámbito de los art. 47 y 148.1.3 CE, toda vez que "la intermediación financiera ha dejado de ser un elemento neutro en el funcionamiento de los mercados de vivienda para ser partícipe directo de las posibilidades de arranque atribuibles a oferta y demanda de vivienda en España», al convertirse "bancos y cajas en un agente más a tener en cuenta en los futuros diseños de política de vivienda» (62).

\section{B. EXISTENCIA DE LEGISLACIÓN ESTATAL SOBRE LA MATERIA}

Las letradas de la Junta de Andalucía y los magistrados discrepantes invocaron la aplicación, por analogía a este supuesto, de la ratio contenida en la STC 37/1988 al entender que el Decreto-ley 6/2013, introduciendo "modificaciones de índole social» no "alcanza a desplegar una efi-

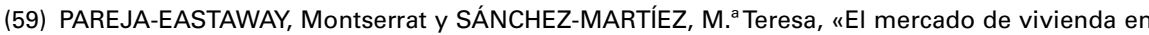
España: la necesidad de nuevas propuestas» en El acceso a la vivienda en un contexto de crisis. Edisofer. Madrid, 2011, pág. 49

(60) HERRERO, Fernando y CREMADES, Víctor, Vivienda y financiación. La oferta del crédito en el nuevo mercado hipotecario y otras formas de acceso a la vivienda. ADICAE. Zaragoza, 2016, pág. 51

(61) Íbid., pág. 43

(62) PAREJA-EASTAWAY, Montserrat y SÁNCHEZ-MARTÍEZ, M. ${ }^{a}$ Teresa, Op. cit., págs. 47 y 48 
cacia incisiva en la política económica general del Estado o en los elementos básicos de la misma» (FJ 7).

La mayoría que subscribe el fallo, sin embargo, rechaza su aplicación por cuanto considera que sí se produce dicha eficacia incisiva, aunque esto resulte altamente cuestionable en términos tanto económicos como jurídicos. Sustentan el fallo sobre la premisa de que el Decreto no desarrolla el derecho a la vivienda, sino que es, en realidad, un instrumento de regulación del mercado hipotecario. Por este último motivo entraría en el ámbito competencial del art. 148.1.13 CE colisionando con la Ley estatal $1 / 2013$, desarrollada en amparo de dicho título.

La interpretación de los títulos «básicos» del Estado y la determinación de su juego competencial ha sido tratada con profundidad por la literatura y la jurisprudencia desde hace décadas, sin embargo, como denuncia Xiol Rius en su voto particular, desde la STC 34/2013, de 14 de febrero, se viene produciendo un giro interpretativo recentralizador que se apoya en el art. 149.1.13 CE. Este movimiento centrípeto ya se había puesto de manifiesto en relación con el derecho de vivienda -aunque de manera más discreta - en las STC 112/2013, de 9 de mayo y 139/2013, de 8 de julio, que resolvían dos conflictos positivos de competencias interpuestos por la Comunidad Autónoma de Madrid, dirigidos contra varios preceptos de los planes estatales de vivienda de 2005-2008 y 2009-2012.

En el conflicto que dio origen a la STC 112/2013, la Comunidad de Madrid argumentaba que el art. 6.1 del plan estatal comporta una invasión de las competencias autonómicas en materia de urbanismo y vivienda. Curiosamente, para el Tribunal no se produce tal invasión ya que, a su juicio, el precepto impugnado no constituye «una regla urbanística, sino una medida básica de política económica que se inserta en la política de vivienda y que encuentra cobertura competencial en el art. 149.1.13 CE» (FJ 5). De manera similar, la STC 93/2015 quiso delimitar el contenido de la competencia autonómica en materia de vivienda afirmando que su desarrollo debía limitarse a "precisar los usos posibles de las edificaciones según el lugar en que se ubiquen dentro de la ciudad o a disciplinar el sector» (FJ 13).

Se observa en la jurisprudencia un desplazamiento del elemento habitacional del art. 148.1.3 CE hacia los títulos competenciales del Estado. El Constitucional está despojando a la competencia en materia de vivienda de su propio contenido, atribuyendo a la regla tercera del apartado primero del art. 148 un valor meramente urbanístico. Si seguimos la tesis delTC, parece que la palabra vivienda nunca haya existido entre las enumeradas por ese precepto y que, por el contrario, se pueda deducir con absoluta claridad de lo preceptuado en el art. 149.1.13 CE.

En un ejercicio de desbordamiento del alcance del art. 149.1.13 CE, el Tribunal ha establecido una prelación jerárquica clara entre este y las 
competencias atribuidas a las Autonomías. El nuevo criterio interpretativo de que se sirve el Constitucional desborda el contenido del título, que ahora habilita al Estado para desarrollar normas en ámbitos constitucionalmente reservados a las Comunidades Autónomas, con todo grado de detalle y concreción, lo que supone, en la práctica, una reconfiguración del esquema de distribución competencial. Cualquier actividad normativa queda supeditada ahora al visto bueno del Estado.

Esta decisión es muy cuestionable, ya desde una perspectiva meramente técnica y es que, ahora, las reglas de distribución competencial se vuelven ya completamente irreconocibles, lo que, en un momento de clara fragmentación del derecho, provoca un alto nivel de inseguridad jurídica tanto para el desarrollo del Derecho administrativo en sí mismo como para los particulares afectados por las normas en cuestión.

En su defensa, el Constitucional sostiene que el criterio no agota la competencia de la Comunidad Autónoma por cuanto seguiría habilitada para el desarrollo de medidas de fomento. Sin embargo, en múltiples ocasiones, su jurisprudencia ha considerado las políticas de fomento diseñadas por el Estado como leyes medida y, por tanto, también dentro del marco del art. 149.1.13 CE, como en la STC 179/1985, de 19 de diciembre, que se pronunciaba sobre la gestión del poder de gasto, o las 188/1989, de 16 de noviembre y 197/1996, de 28 de noviembre (63). No resultaría extraño, por ello, que el Estado, en amparo de dichos pronunciamientos, desarrollase también medidas de fomento en materia de vivienda que afectasen a la Comunidad andaluza y que pudiesen ser avaladas a posteriori.

Es más, ya la STC 139/2013 justificaba su fallo argumentando, respecto del texto impugnado y finalmente convalidado, que: «la reforma no obsta para que las Comunidades Autónomas establezcan su propia política de vivienda, en la que podrán introducir el régimen de intervención administrativa que resulte acorde con la finalidad perseguida" (FJ 4). Dos años después, dicho régimen de intervención administrativa ha sido nuevamente acotado en lo que parece una reformulación encubierta del sistema competencial.

\section{TRANSgREsión de LAS bases estatales}

A juicio del tribunal, el Decreto-ley andaluz «rompe» con la legislación del Estado y por ello no pasa el test de constitucionalidad. Concreta-

(63) Cfr. CARRASCO DURÁN, Manuel, "La interpretación de la competencia del Estado sobre las bases y la coordinación de la planificación general de la actividad económica (art. 149.1.13a de la Constitución)" en Revista de derecho político núm. 62, 2005, pág. 72 
mente, con el art. 1 del Real Decreto-ley $1 / 2015$ de 27 de febrero de mecanismos de segunda oportunidad, que establece un plazo de suspensión de siete años(64) para los lanzamientos que se adopten en la ejecución de una deuda hipotecaria contra la vivienda habitual de determinados sujetos vulnerables. Sin embargo, como critican Ponce(65) y los cuatro magistrados que subscribieron los votos particulares, el Tribunal no motiva su alegación, se limita a declarar la incompatibilidad sin más.

Si examinamos el contenido de las normas de contraste vemos que, en realidad, no existe contradicción. Al contrario: las normas producen sus efectos en momentos temporales distintos. Como explica la magistrada Asua Batarrita en su voto, la previsión andaluza solo puede aplicarse cuando finalice el plazo de suspensión de la previsión estatal, decretándose el lanzamiento, "pues solo a partir de entonces podría producirse el supuesto de hecho previsto por la norma andaluza», no hay por tanto incompatibilidad, sino mera "sucesión de normas en el tiempo". Y es que la norma andaluza, configurada como una medida expropiatoria, requiere que se haya producido el efectivo traslado de la propiedad, resultando, así, materialmente imposible la superposición de las normas invocadas.

Es más, parece muy cuestionable presumir que la norma andaluza incida con mayor intensidad que la estatal en la ordenación del sector económico de la vivienda, por cuanto el Decreto-ley 6/2013 no afecta a la ejecución al producir sus efectos con carácter inmediatamente posterior, mientras que la Ley 1/2013 retiene la propiedad en manos del ejecutado durante el plazo legalmente determinado.

Motivo este por el que tampoco podemos compartir la lectura de la magistrada Encarnación Roca Trías que, en su voto particular, defiende que la norma andaluza conlleva una invasión del título contenido en el art. 149.1.6 CE que habilita en exclusiva al Estado para el desarrollo de legislación procesal, por afectar a la normal ejecución de las garantías hipotecarias.

La expropiación forzosa produce sus efectos una vez finalizado el proceso de ejecución hipotecaria y fuera de él - no tendría sentido de otro modo-, con la misión de mitigar su impacto sobre determinados sujetos vulnerables. No condiciona en absoluto su desarrollo, ni tampoco busca substituirlo con un procedimiento alternativo o, si quiera, con un resultado substancialmente distinto, habida cuenta de que se trata, al fin y al cabo, de una expropiación de uso de tan solo tres años de duración.

(64) Sin embargo, el deis a quo para el plazo de suspensión es el de la aprobación de la Ley para todos los desalojos. Es decir, se produce la paralización de los lanzamientos, con independencia de cuando se hayan iniciado, hasta el año 2020, dejando de producir efectos más allá.

(65) PONCE, Op. cit., "¿Ha expropiado el Tribunal Constitucional las competencias autonómicas en materia de vivienda?" 
No parece, por tanto, que sea incompatible con la normativa básica estatal en ninguna de sus manifestaciones. Las diferencias entre la norma impugnada y la norma de contraste son, o bien meramente técnicas, o bien responden a motivaciones políticas diferentes, pero jurídicamente compatibles. Estas diferencias forman parte del desarrollo democrático de un Estado descentralizado y en este sentido caminaba la ratio fijada por la STC 37/1988 que fue invocada por la defensa de la Junta de Andalucía en la tramitación de este recurso. En aquel pronunciamiento, para el Constitucional, la mera diferencia técnica o política no comportaba una incidencia suficiente en el título competencial del Estado como para generar la declaración de inconstitucionalidad.

La tesis actual del Tribunal parece asentarse más en un juicio de oportunidad que en uno de constitucionalidad. La norma andaluza no es incompatible con la estatal, sino políticamente discordante. En palabras de Ponce, el TC está "construyendo el art. 149.1.13 como un precepto excluyente de alternativas políticas y no como lo que le corresponde ser desde una perspectiva técnico-jurídica: la garantía de unas bases estatales en el sector económico" (66).

\section{Un paso adelante: el caso de la STC $62 / 2016$}

El derecho a la vivienda está íntimamente ligado al principio de la dignidad humana, como se evidencia en la propia dicción del artículo 47 CE cuando se refiere a una "vivienda digna y adecuada». La relación real entre la dignidad y la vivienda es difícilmente determinable en términos subjetivos y su distribución en el ordenamiento es tremendamente difusa - como lo es también el derecho a la vivienda en sí mismo - si bien, tradicionalmente, se viene entendiendo que alcanza unos mínimos requisitos de superficie, salubridad, seguridad y comodidad (67).

En el 2008 un 13,1\% de la población bajo el umbral de la pobreza no podía mantener su vivienda a una temperatura adecuada y un $9,6 \%$ aquejaba retrasos en el pago de las facturas de suministros básicos. En 2015 se trataba ya de un $23,3 \%$ y un $22,1 \%$ respectivamente (68). La pobreza energética es un asunto estrechamente vinculado al derecho a la vivienda y tanto es así que una de las dos principales normas que se desarrollaron

(66) Íbid.

(67) Cfr. IACONO, Geneviève, "Las frágiles bodas del principio de dignidad y del derecho a la vivienda" El Cronista del Estado social y democrático de Derecho núm. 61-62, pág. 24

(68) Cfr. Consejo Económico y Social, Políticas Públicas Para Combatir La Pobreza En España. CES. Madrid, 2017, pág. 158 
en Cataluña frente a este fenómeno contenía disposiciones tanto en materia de pobreza energética como en materia habitacional.

La otra norma es el Decreto-ley 6/2013 por el que se modificó el Código de Consumo de Cataluña, recurrido por el Gobierno por colisionar con la Ley $24 / 2013$ del sector eléctrico y la Ley 34/1998 de hidrocarburos e invadir los títulos del art. 149.1.13 y 149.1.25 CE. El recurso se resolvió en la reciente STC 62/2016(69), caracterizada por el mismo criterio uniformador y recentralizador de la STC 93/2015, sancionando discrepancias de criterio como si fuesen incompatibilidades normativas.

Sin embargo, en este pronunciamiento el Tribunal da un paso más allá. Sostiene que el Estado adaptó las Directivas 2009/72/CE y 2009/73/CE protegiendo al consumidor vulnerable a través de la financiación del precio del suministro de la electricidad y gas "y no mediante el establecimiento de prohibiciones de desconexión del suministro" (FJ 10). En su opinión, esta decisión tiene un carácter excluyente, algo, por otra parte, difícilmente deducible de la lectura de las Directivas, que no disponen con carácter excluyente sino meramente alternativo, como se infiere de los art. 3.7 y 3.3 de los respectivos instrumentos: "cada uno de los Estados miembros definirá el concepto de cliente vulnerable que podrá referirse a la pobreza energética $y$, entre otras cosas, a la prohibición de desconexión de dichos clientes en períodos críticos».

El desarrollo del Decreto no resultaría, por tanto, incompatible con normas positivas, identificables e interpretables, con instrumentos o mecanismos diseñados por el Estado, sino con una voluntad difusa y velada que, hasta ahora, solo el Tribunal Constitucional ha sacado a relucir. $Y$ lo hace, como sucedía en la sentencia anterior, para dejar claro que no consiente que se exceda el nivel de protección pública fijada por el Estado. Se trata de una estrategia claramente centralizadora que limita las capacidades de las Autonomías de establecer políticas propias (70).

El ejecutivo catalán amparó el desarrollo del Decreto-ley en sus competencias en materia de "consumo», "energía" y "servicios sociales", pero en opinión del Constitucional los preceptos impugnados en realidad están afectos a los títulos estatales en materia de bases y coordinación de la economía y de bases del régimen energético y minero por cuanto «inciden directamente en la configuración del contenido del régimen jurídico de uno de los sujetos que intervienen en el sector eléctrico y de gas, al

(69) Puede ser de interés la consulta del Auto 23/2015 que se pronuncia sobre el mantenimiento de la suspensión del Decreto catalán, cuyo estudio, al igual que el del Auto 244/2013, excede el contenido de este trabajo. Puede accederse en línea a esta resolución en http://hj.tribunalconstitucional.es/ es/Resolucion/Show/24357

(70) Vid. AGUADO I CUDOLÀ, Vicenç y PRADO, Raquel, "Derecho a la protección de la salud y exclusión de la asistencia sanitaria: la crisis económica como pretexto para la limitación del acceso a los servicios y prestaciones del estado del bienestar» en RVAP núm. 99-100, 2014 
afectar directamente a sus obligaciones y derechos, y también conciernen a la garantía del suministro".

Nuevamente, se produce un desplazamiento de los títulos con contenido en materia de protección pública (vivienda, servicios sociales, consumo) en favor de títulos que arbitran relaciones económicas y mercantiles. El argumento es, otra vez, la protección de la unidad del mercado en España y, en la práctica, la protección de sujetos privilegiados en relaciones económicamente desiguales: el sector financiero y el sector energético. Esta lectura es cuestionable toda vez que, como bien señala Xiol Rius en su voto, no existe jurisprudencia consolidada sobre la determinación de las bases del sector energético. Y, como afirma Carrasco, "una de las principales finalidades con la que el Estado suele utilizar la competencia del artículo 149.1.13. ${ }^{a}$ de la Constitución viene a ser la de llevar a cabo la ordenación básica de sectores de la actividad económica con respecto a los cuales la Constitución no le reconoce a aquél competencia específica alguna» (71).

Así mismo, en todo caso, aun adscribiendo la regulación al ámbito del art. 149.1.13 y del art. 149.1.25 CE, no se puede atribuir el desarrollo de todo tipo de legislación sobre la materia al Estado, a riesgo de desconocer la estructura descentralizada sobre la que se asienta nuestro ordenamiento (72).

\section{Conclusiones}

El derecho a la vivienda es un derecho con dimensión tanto objetiva como subjetiva. Su exigibilidad, sin embargo, no es directa, como en el caso de los derechos civiles y políticos, sino que debe ser reconocida en la legislación ordinaria con un cauce procedimental y procesal al efecto

$\mathrm{Al}$ analizar qué sujetos han incorporado a nuestro ordenamiento este contenido subjetivo y de qué manera lo han hecho, se puede apreciar lo que parece una correlación entre el desarrollo de dicho contenido y la descentralización legislativa. De manera que, mientras que las Comunidades Autónomas se han colocado en la vanguardia del proceso de subjetivación, generando instrumentos, procedimientos y acciones que dotan de exigibilidad al derecho, los poderes centrales se han mantenido en una posición más conservadora, llegando a frenar, en ocasiones, la iniciativa autonómica.

(71) CARRASCO DURÁN, Op. cit., pág. 66

(72) Cfr. PONCE, Juli, "La sentencia del Tribunal Constitucional contra la pobreza energética» en Agenda Pública, 2016 [Consultado en línea el 26 de mayo de 2017 en http://agendapublica.elperiodico.com/la-sentencia-del-tribunal-constitucional-sobre-la-pobreza-energetica/] 
Los poderes autonómicos, aunque con ciertas carencias en términos de técnica legislativa, han incorporado a nuestro ordenamiento dos elementos fundamentales e innovadores en materia de vivienda. En primer lugar, han introducido un nuevo aspecto de la vertiente subjetiva del derecho de habitación: el derecho a no ser expulsado de la vivienda habitual, que hasta ahora solo se encontraba de manera puntual en la jurisprudencia europea. Y, en segundo lugar, han incorporado la acción pública para demandar la entrega efectiva y material de una residencia.

El poder central, en cambio, se ha aproximado a la competencia en materia de vivienda desde una perspectiva más conservadora. Entiende el derecho como un mero principio rector y así lo ha configurado en las ocasiones en que se ha decidido a legislar sobre esta cuestión. Así mismo, se ha opuesto a las reformas autonómicas surgidas a partir de 2013, iniciando sendos recursos de inconstitucionalidad ante el Tribunal Constitucional, sostenidos - como ilustra el recurso al Decreto-ley 6/2013 de Andalucía - por una posición más próxima a los intereses de los mercados y las entidades financieras que al desarrollo de los derechos sociales.

Esta correlación también parece manifestarse en otros Estados vecinos, como el caso del Reino Unido, cuyo sistema de descentralización recuerda al que vertebra nuestro ordenamiento. La Administración escocesa, en opinión de algunos autores, destaca por haber generado una normativa en materia de vivienda que no solo supera los estándares británicos previos a la descentralización sino, también, los actuales estándares internacionales. Lo cual habría logrado en ejercicio de una "carrera hacia arriba» en términos de competencia interregional, que los habría llevado a profundizar en la universalización del derecho.

ElTribunal Constitucional solo se ha pronunciado, por el momento, sobre una de las ocho normas autonómicas aprobadas desde 2013. El Tribunal ha seguido las tesis del Estado y ha declarado inconstitucional el procedimiento andaluz de expropiación forzosa. Lo ha hecho en una aproximación meramente competencial, denunciando la falta de competencia de las Comunidades Autónomas para regular en materia de vivienda cuando se afecta, también, a aspectos centrales de la economía como el mercado hipotecario. Esta misma idea la ha reproducido después en la sentencia sobre el Decreto 6/2013 de Cataluña de pobreza energética. Se trata, en la práctica, de un movimiento materialmente recentralizador que, al mismo tiempo, entorpece el desarrollo del contenido subjetivo de los derechos sociales.

En nuestro ordenamiento, la centralización legislativa en materia de vivienda amenaza con frenar la progresión de la subjetivación del derecho. Por el contrario, los marcos de regulación descentralizados favorecen una competencia horizontal que ampara el ensanchamiento de los 
títulos sociales, universalizándolos y volviéndolos exigibles. La descentralización ha favorecido, aquí y en otros ordenamientos, la generación de instrumentos que presentan innovaciones tan interesantes que han sido asumidas, posteriormente, por los mismos poderes centrales que, en un principio se oponían a ellas, como hemos visto respecto del proyecto de Plan estatal de vivienda para el periodo 2018-2021, que incluye matices y aspectos que fueron aportados por la ola autonómica de reformas de 2013.

Parecen oportunas, por tanto, como síntesis para concluir este análisis, las reflexiones de Gerardo Pisarello y Marco Aparicio: «El constitucionalismo debería abandonar su obsesión por la unidad, por el principio de jerarquía y por la decisión en último término. En su lugar, debería dar lugar a un panorama en el que el principio de competencia, así como los mecanismos horizontales y verticales de resolución consensuada de los conflictos, tuvieran un mayor papel» (73).

Trabajo recibido el 11 de septiembre de 2017

Aceptado por el Consejo de Redacción el 20 de octubre de 2017

(73) APARICIO WHILELMI, Marco y PISARELLO, Gerardo, «El reconocimiento de derechos, deberes y principios en los Estatutos de Autonomía: ¿hacia una comprensión multinivel o en red de la protección de los derechos?» en El clip, núm. 42, 2007, pág. 14 
LABURPENA: Etxebizitzarako eskubidearen garapenean legeria deszentralizatzeak duen inpaktua jorratzen da lan honetan; zehazki, alderdi subjektiboari dagokionez. Hurbilketa honetan, etxebizitzarako eskubidearen garapenaren ikuspegi historikoa hartzen da abiapuntutzat, eta eremu konparatuan alderatzen da eredua. Era berean, Andaluzian, Kanarietan, Nafarroan, Katalunian, Euskal Autonomia Erkidegoan, Valentzian, Extremaduran eta Balear irletako lege-proiektuan etxebizitza-arloan onartu diren arau autonomikoen edukia aztertzen da, eta Konstituzio Auzitegiaren maiatzaren 14ko 93/2015 Epaiaren zuzenbide-oinarrien azterketarekin alderatzen dira arau autonomiko horiek. Epai horretan, Andaluziako Etxebizitzaren Legearen kontra formulatu zen konstituzio-kontrakotasuneko errekurtsoa ebatzi zen. Ondorioa honako hau da: eskumen-esparru deszentralizatuek, orain artean eta baliteke etorkizunean ere hala izatea, mesede egin diote Administrazio Publikoaren eta Administrazioarekiko Auzi Epaitegien aurrean etxebizitzarako eskubidea galdagarri egiten duten tresnak eratzeari.

GAKO HITZAK: Etxebizitza izateko eskubidea. Deszentralizatzea. Eskumen-banaketa. Nahitaezko desjabetzea. Gizarte-bazterketa

RESUMEN: Este trabajo se aproxima al impacto de la descentralización legislativa en el desarrollo del derecho a la vivienda, en concreto de su aspecto subjetivo. En esta aproximación se toma una perspectiva histórica de dicho desarrollo y se contrasta el modelo en el ámbito comparado. Se analiza, así mismo, el contenido de las normas autonómicas en materia de vivienda aprobadas en Andalucía, Canarias, Navarra, Cataluña, País Vasco, Valencia, Extremadura y el proyecto de ley balear y se contrastan con el análisis de los fundamentos de derecho de la Sentencia del Tribunal Constitucional 93/2015 de 14 de mayo que resuelve el recurso de inconstitucionalidad formulado contra la ley andaluza de vivienda. Se llega a la conclusión de que los marcos competenciales descentralizados han favorecido, hasta ahora, y podrían seguir favoreciendo en un futuro, la articulación de instrumentos que vuelven exigible el derecho a la vivienda ante la Administración Pública y los Juzgados de lo Contencioso-administrativo.

PALABRAS CLAVE: Derecho a la vivienda. Descentralización. Distribución de competencias. Expropiación forzosa. Exclusión social.

ABSTRACT: This work draws closer to the impact of legislative decentralization in the development of the right to housing, particularly of its subjective aspect. On this approach a historical perspective is taken regarding such development and the model is set against in the comparative area. Likewise, the content of rules in force in the Autonomous Communities in the field of housing passed in Andalusia, Canary Islands, Navarra, Cataluña, Basque Country, Valencia, Extremadura and the bill of Balearic Islands are analyzed and they are set against the analysis of the legal basis of the Constitutional Court judgment $93 / 2014$ of May $14^{\text {th }}$ which determines the action on unconstitutionality made against the Andalusian Act on housing. It was concluded that the 
decentralized competence framework have so far favoured and could further in the future the articulation of legal tools that could make effective the right to housing before the Public Administration and the Contentious-Administrative courts.

KEYWORDS: Right to housing. Decentralization. Distribution of Competences. Expropriation. Social exclusion. 